\title{
Functional responses of zooplankton communities to depth, trophic status, and ion content in mine pit lakes
}

\author{
Anna Maria Goździejewska (iD · Jacek Koszałka • Renata Tandyrak • \\ Jolanta Grochowska • Katarzyna Parszuto
}

Received: 3 June 2020/Revised: 22 March 2021 / Accepted: 9 April 2021 / Published online: 27 April 2021

(C) The Author(s) 2021

\begin{abstract}
Functional traits can be used to identify various ecosystem processes that are influenced by natural and anthropogenic factors. We tested the hypothesis that the species composition and functional feeding traits of zooplankton are influenced by environmental gradients, such as depth, trophic status, and ion content. This hypothesis was tested in three lignite strip mine lakes in Central Poland. Two shallow, polymictic lakes were reclaimed (1994 and 2008), and the third deep, stratified lake has been reclaimed during the flooding process, since 2011. Samples were collected monthly in 2016 and 2017. The functional responses of zooplankton communities to environmental variables were tested through redundancy analyses. Both eutrophy and oligotrophy contributed to the taxonomic heterogeneity and functional
\end{abstract}

Handling editor: Andrew Dzialowski

Supplementary Information The online version of this article (https://doi.org/10.1007/s10750-021-04590-1) contains supplementary material, which is available to authorized users.

A. M. Goździejewska $(\bowtie) \cdot$ J. Koszałka

Department of Tourism, Recreation and Ecology,

University of Warmia and Mazury in Olsztyn,

Oczapowskiego 5, 10-719 Olsztyn, Poland

e-mail: gozdzik@uwm.edu.pl

R. Tandyrak · J. Grochowska $\cdot$ K. Parszuto

Department of Water Protection Engineering, University of Warmia and Mazury in Olsztyn, Prawocheńskiego 1, 10-719 Olsztyn, Poland homogeneity of zooplankton. In eutrophic condition small microphagous rotifers and small-sized crustaceans dominated, while oligotrophy and high ion concentrations favored dominance of large microphagous and stationary/suspended feeders. In turn, the depth gradient of a newly emerging, stratified lake resulted in taxonomic and functional heterogeneity of zooplankton. Our results complement existing knowledge about zooplankton in post-industrial areas, and also provide new information on the mechanisms of formation and functioning of mine pit lake ecosystems.

Keywords Functional traits - Ecological interactions · Environmental gradients · Trophic status $\cdot$ Geochemical properties

\section{Introduction}

Functional traits are used to explain variation in the structure and function of zooplankton communities in aquatic ecosystems. The application and interpretation of functional traits requires a comprehensive ecosystem approach, where the diversity and distribution of traits in communities of co-existing species are associated with ecosystem structure and environmental processes (Barnett \& Beisner, 2007; Vogt et al., 2013; Pomerleau et al., 2015; Obertegger \& Flaim, 2018; Sodré \& Bozelli, 2019; Simões et al., 2020). The 
functional diversity of zooplankton is usually analyzed by grouping species with similar morphological, physiological and ecological traits. Unlike conventional analyses of taxonomic diversity, this approach does not focus on individual species (Naeem \& Wright, 2003; Boersma et al., 2016). Therefore, communities with similar functionalities are not necessarily composed of the same species, but they are characterized by the same pattern of functional traits, such as body size, feeding strategy and habitat utilisation (Barnett \& Beisner, 2007; Oh et al., 2017; Sodré \& Bozelli, 2019; Simões et al., 2020).

According to community assembly theory, the composition, structure and functionality of zooplankton communities are determined by environmental filters and competition (Booth \& Swanton, 2002). Environmental filters are abiotic factors (e.g. temperature, depth, water trophy, salinity) that eliminate nonadapted species and, by forming groups with common ecological tolerance, lead to the homogenization of traits. In contrast, competition acts as a factor of trait divergency that leads to the ecological differentiation or homogenization of co-existing zooplankton species. In the competition for common resources, the more efficient competitor wins, and the number of species decreases. However, there are also species in the community whose functional traits allow them to use a different food resource. Consequently, the presence of different functional groups in an ecosystem compensates and the community becomes functionally and often taxonomically heterogeneous. According to Cornwell et al. (2006), both environmental filters and competition occur simultaneously, but they have different consequences for the ecological functionality of communities. Chesson (2000) highlights that both environmental filters and competition can lead to trait similarity and dissimilarity, and the final result depends on the robustness of ecosystem mechanisms.

The analyses of functional traits support the identification of ecosystem phenomena that are not revealed by taxonomic analyses (Barnett \& Beisner, 2007; Parravicini et al., 2014).

Zooplankton functional traits allow for the identification of the mechanisms that are responsible for various environmental gradients in aquatic ecosystems, including trophic levels, primary productivity (Barnett \& Beisner, 2007; Obertegger \& Manca, 2011; Oh et al., 2017; Moody \& Wilkinson, 2019), temperature (Lokko et al., 2017; Obertegger \& Flaim, 2018), depth (Gauthier et al., 2014; Obertegger \& Flaim, 2018), hydrological regime (Galir Balkić et al., 2018), salinity (Lokko et al., 2017; Gutierrez et al., 2018) and anthropogenic activity (Simões et al., 2020). The functional traits of zooplankton related to their feeding strategies have been used both to interpret functioning mechanisms in food webs (Kim et al., 2000) and to evaluate the impact of environmental pollution (acidification, turbidity) on ecosystem health and resilience (Hogsten et al., 2009; Petchey et al., 2009; Moreira et al., 2016; Goździejewska et al., 2019a). Many studies have shown that zooplankton functional traits can be homogenized due to extreme environmental gradients including high trophic and primary productivity (Moody \& Wilkinson, 2019), high salinity (Gutierrez et al., 2018), small or large suspended particles (Goździejewska et al., 2019a), high anthropogenic impact (Simões et al., 2020). In turn, an intermediate range of factors or spatial variation in conditions (e.g. habitat diversity related to depth) results in taxonomical and functional heterogeneity of zooplankton (Gauthier et al., 2014; Goździejewska et al. 2019a).

Most studies on zooplankton functional traits have been conducted in natural ecosystems using long-term datasets. However, there is a general scarcity of observations concerning the functional diversity of artificial reservoirs with a much shorter history, including mine pit lakes whose number continues to increase in reclaimed mining sites. Pit lakes occupy basins created by strip mining (Nixdorf et al., 2005; Gammons et al., 2009; Sloss, 2013). The flooding of excavated pits is often used to reclaim former mines to remedy environmental disturbance resulting from strip mining (Larondelle \& Haase, 2012; Blanchette \& Lund, 2016; Stachowski et al., 2018), and it delivers social and environmental benefits (McCullough \& Lund, 2006; Lei et al., 2016; Lechner et al., 2017). Newly constructed aquatic ecosystems quickly integrate into the local environment and landscape, and biological succession processes occur in these ecosystems (Kalin et al., 2001; Gammons et al., 2009; Goździejewska et al. 2019b). The rate and direction of transformations are influenced by the morphometric and geochemical properties of excavated pits and the hydrological regime (Kumar et al., 2009; Larondelle \& Haase, 2012; Sloss, 2013). The geologic structure of the area and the groundwater quality are the main 
factors determining the primary composition and chemical properties of water. Similarly to natural ecosystems, the land-use pattern in the direct catchment, the quality of inflows from the catchment, and the type and intensity of lake use play an important role in the development of mine pit lakes (Axler et al., 1998; Kleeberg et al., 2008). The sensitivity of these relatively young environments can be analyzed based on selected functional traits of the colonizing species to expand our understanding of numerous ecological relationships and to identify potential threats (ElBassat \& Taylor, 2007; Marszelewski et al., 2017). This is an important consideration for preserving water resources created in former industrial areas that are devoid of natural lakes.

This study analyzed zooplankton structure in three mine pit lakes (Janiszew, Przykona and Władysławów) which had been formed as a result of a land reclamation project initiated by the Adamów Coal Mine in former lignite strip mines in Central Poland. The first limnological studies of lakes Janiszew and Przykona were carried out by Marszelewski et al. (2017), whereas Lake Władysławów was previously analyzed by Goździejewska et al. (2019b) and Skrzypczak et al. (2019). These studies revealed differences in the rate and direction of ecological succession in the analyzed lakes, which can be attributed to the lakes' age, morphometric traits, and catchment characteristics. Two environmental characteristics, depth and trophic state, were identified as potential determinants of lake functionality. The depth of the lake determined the water mixing dynamics, thermal and oxygen conditions, while the trophic level determined nutrients concentration. The aim of this study was to investigate the impact of depth and trophic gradients on planktonic communities. We hypothesized that the species composition and functional feeding traits of zooplankton would be different in lakes vary of depth and trophic status. We also noted the importance of geochemical properties, such as ion concentrations in the water. We expected that an increase in water trophy will result in taxonomic and functional homogenization of the zooplankton. In turn, an increase of depth gradient will favor the heterogeneity of these zooplankton characteristics. This study complements existing knowledge and provides new information about the functioning of food webs in mine pit lakes.

\section{Materials and methods}

Study area

The study was conducted in three mine pit lakes located in the vicinity of the Turek-Adamów lignite strip mine: Janiszew (JAN), Przykona (PRZ) and Władysławów (WLA) (Fig. 1). The lakes vary in age, depth and basin shape based on the mining operations that were present. They also differ in the type of direct catchment and form of use, depending on ownership rights and land-use types prescribed in the local zoning plan (Różkowski et al., 2010; Marszelewski et al., 2017; Goździejewska et al., 2019b; Table 1). PRZ is the oldest (1994), largest and shallowest of the lakes, and it occupies the former opencast mine in Adamów (OM-A; Fig. 1). PRZ was supplied with water from the Teleszyna River and groundwater removed from the mine. This polymictic lake has a regularly shaped basin, a flat bottom, gently sloping shores and high water mixing dynamics at average depth $(4.3 \mathrm{~m})$ (Marszelewski et al., 2017; Goździejewska et al., 2019b). The lake became municipal property in 2004 , and it has experienced considerable recreational pressure since that time. Residential buildings, recreational facilities, bathing areas, an angling base, and a slip for launching motor boats have been developed in the lake's direct catchment (Różkowski et al., 2010). Goździejewska et al. (2019b) reported an increase in water trophy of PRZ.

In 2008, the basin of JAN was filled with water removed from the opencast mine in Koźmin (OM-K; Fig. 1). The morphometric traits and the water mixing regime in JAN are similar to those noted in PRZ, and the lake's water turns over from top to bottom during the year (Supplementary Fig. S1). JAN has an average depth of $6.5 \mathrm{~m}$. It is surrounded by fallow land and fields directly along its shoreline. The lake and its immediate surroundings are owned by the mine, and fishing and other recreational activity are prohibited (Marszelewski et al., 2017; Goździejewska et al., 2019b).

WLA occupies the former Władysławów strip mine which has been reclaimed by long-term flooding since 2011 (Różkowski et al., 2010; Stachowski et al., 2018). The lake does not have an outflow, and it is supplied mainly with groundwater, rain water and catchment water. Unlike PRZ and JAN, WLA is a deep lake whose maximum depth was estimated at 


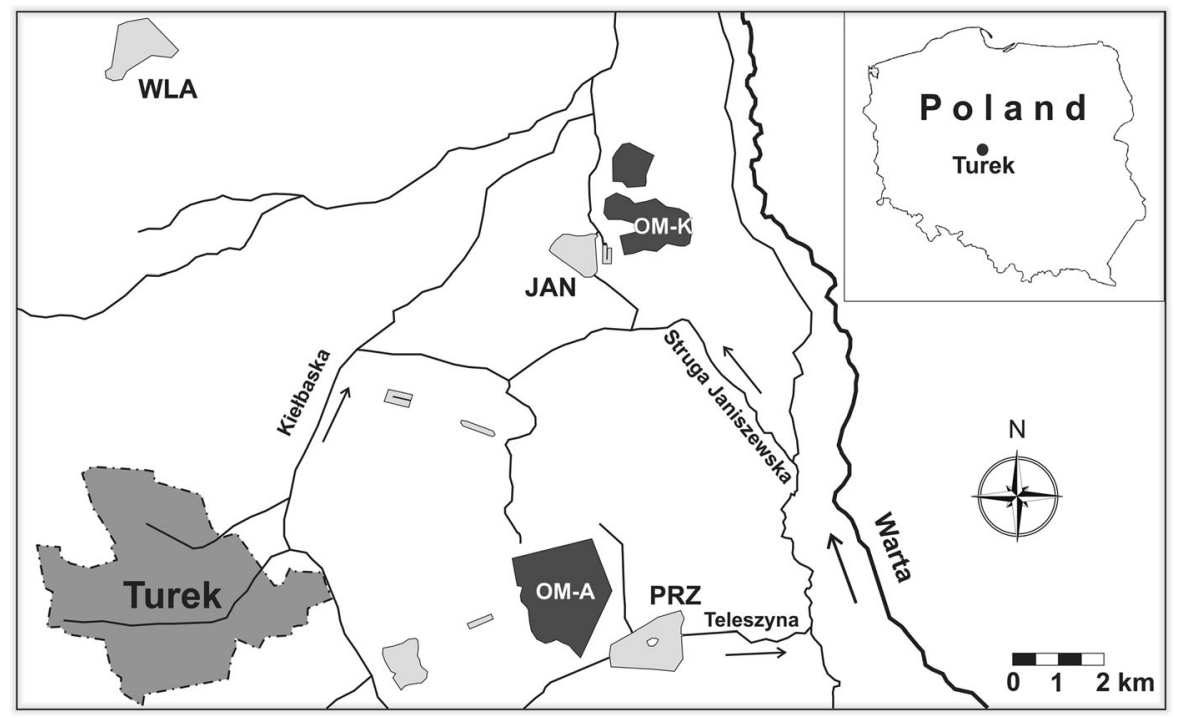

Fig. 1 Location of the study area. Abbreviations: $O-M A$ Adamów opencast mine, $O-M K$ Koźmin opencast mine, JAN lake Janiszew, PRZ lake Przykona, WLA lake Władysławów

$25 \mathrm{~m}$ during the study (the maximum target depth is $37 \mathrm{~m}$, with an estimated average of $21.5 \mathrm{~m}$ ). Steep slopes with an inclination angle of up to $30 \%$ account for around $80 \%$ of the shore line. The remaining part of the shoreline features gentle slopes. The lake is characterized by thermal and oxygen stratification in summer (Supplementary Fig. S1). The flooding process has not yet been completed, the lake constitutes the property of the mine, and it is not open to the public.

Sampling and analytical procedure

Zooplankton were sampled every four weeks between July and October 2016, and between May and September 2017. A single sampling sites was located in the deepest part of each lake. In shallow, polymictic lakes PRZ and JAN, samples were collected between the surface and the bottom at a depth of $0,2,4$ and $6 \mathrm{~m}$ (PRZ) and 0, 3, 5 and $8 \mathrm{~m}$ (JAN), and combined into single samples for each lake. This layer was defined as the epilimnion due to the polymictic and homothermic character of the entire water column. In the deep, stratified lake WLA, zooplankton samples were collected at three depths: 0-5 m, 6-10 m and 15-20 m. These layers were formed within the reach of the epilimnion, metalimnion and hypolimnion, respectively, during the summer stagnation period. All samples from the three lakes were collected with a 51 Patalas trap. Samples of 201 from each layer were passed through a plankton net with $30 \mu \mathrm{m}$ mesh size, preserved in Lugol's solution, and fixed in $2 \%$ formalin solution. During the experiment, a total of 45 zooplankton samples were collected, including 9 PRZ, 9 JAN, and 27 WLA.

Zooplankton were identified under a Zeiss AXIO Imager microscope to the lowest possible taxonomic level (with the exception of Copepoda juvenile stages) using the methods described by von Flössner (1972), Koste (1978), Ejsmont-Karabin et al. (2004), Rybak \& Błędzki (2010), and Błędzki \& Rybak (2016). Quantitative analyses involved the determination of zooplankton abundance (ind $1^{-1}$ ) with a Sedgewick-Rafter counting chamber. Zooplankton biomass $\left(\mathrm{mg} \mathrm{l}^{-1}\right)$ was determined according to the methods proposed by Bottrell et al. (1976) and Ejsmont-Karabin (1998).

The rotifer (TSI ROT) and crustacean (TSI CRU) indices were used to evaluate the trophic state (TSI ZOO) of the analyzed lakes, based on the method described by Ejsmont-Karabin (2012) and EjsmontKarabin \& Karabin (2013).

The taxonomic variability of zooplankton was evaluated with the dominance index (D) (Kasprzak and Niedbała, 1981), diversity index (Shannon's index $H^{\prime}$ ) and evenness index (Pielou's index $J^{\prime}$ ). The taxonomic diversity and similarity of zooplankton 


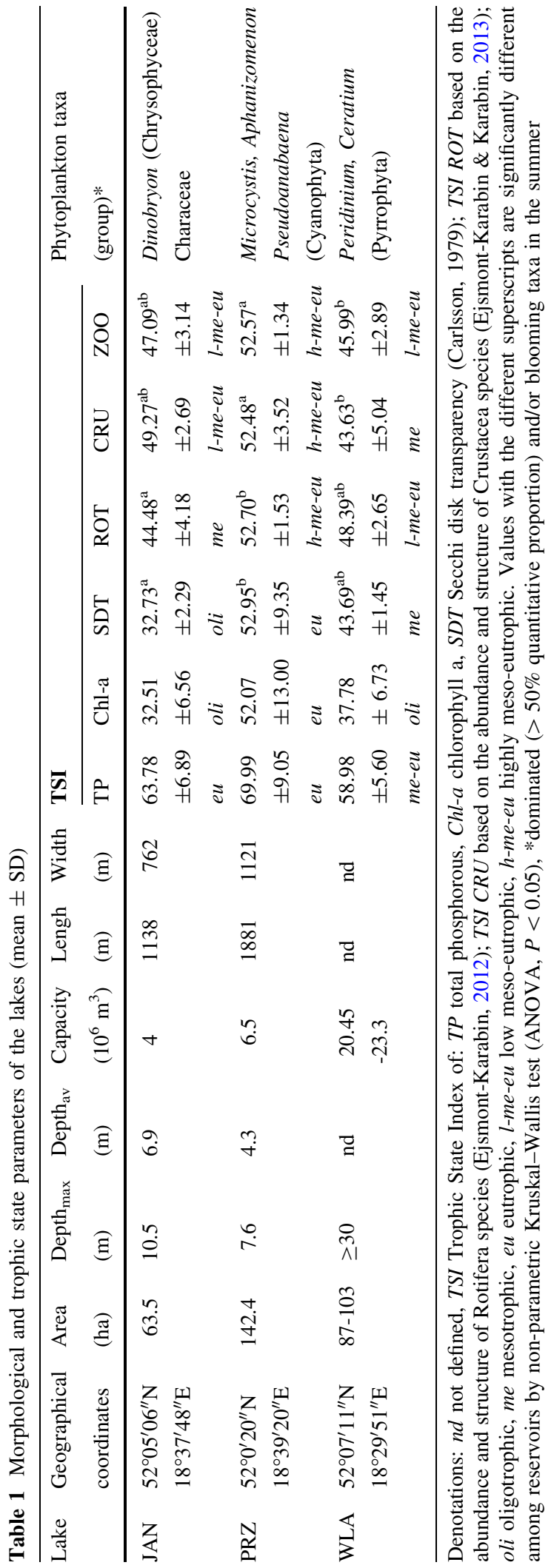

communities (Bray-Curtis and Sorensen's indices) was calculated based on mean species abundance (ind $1^{-1}$ ) colonizing the epilimnion layer of the lakes and was compared with the use of MVSP 3.22 software (Kovach, 2015).

To assess the functional variability of zooplankton, we used traits based on body size and feeding strategies. On this basis, rotifer and crustacean species were classified into four groups: small microphagous (SMF), large microphagous (LMF), raptorials (RAP), and stationary/suspended (STA/SUS) feeders, with the use of the methods described by Obertegger et al. (2011), Bertani et al. (2012), Vogt et al. (2013), and Moreira et al. (2016).

The ratio of trophic groups (GR') in the zooplankton was determined to characterize ecosystem functionality of the lakes (Smith et al., 2009; Obertegger et al., 2011). GR' was calculated for the mean biomass $\left(\mathrm{mg} \mathrm{l}^{-1}\right)$ of each functional groups in the entire water column, from the surface to the bottom of each lake, with the following formula:

$\begin{aligned} \mathrm{GR}^{\prime}= & \sum(\text { raptorial biomass }- \text { microphagous biomass }) / \\ & \sum(\text { total zooplankton biomass })\end{aligned}$

The values of GR' ranged from -1 to 1 . Values below 0 indicate the dominance of microphagous feeders, and values higher than 0 denote the dominance of raptorial feeders.

To determine the response of zooplankton trophic groups to environmental variables, we used a grazing rate coefficient. The grazing rates for each feeder type were calculated as a function of the biomass of zooplankton feeding on phytoplankton (Lampert, 1988):

$\gamma=4.5+231 W$

where: $\gamma$ is the grazing rate $\left(\%\right.$ day $\left.^{-1}\right)$ and $W$ is the biomass of zooplankton trophic groups $\left(\mu \mathrm{g}^{-1}\right)$.

The physical and chemical parameters of water were analyzed in each site and at every sampling depth. Water temperature $\left(\mathrm{T},{ }^{\circ} \mathrm{C}\right), \mathrm{pH}$ and dissolved oxygen (DO, $\mathrm{mg} \mathrm{l}^{-1}, \%$ ) were measured with the YSI 6600 V2 Multi-Parameter Water Quality Sonde. A Secchi Disk was used to measure transparency (SDT, m). Water samples were collected for laboratory analyses of color (HAZEN scale), turbidity (NTU), electrical conductivity (EC, $\mu \mathrm{S} \mathrm{cm}^{-1}$ ), total suspension (SUS, $\mathrm{mg} \mathrm{l}^{-1}$ ), total hardness ( $\mathrm{TH}$, 
mval $1^{-1}$ ) and alkalinity ( $\mathrm{MC}, \mathrm{mval} \mathrm{l}^{-1}$ ), chloride $\left(\mathrm{Cl}^{-}, \mathrm{mg} \mathrm{l}^{-1}\right)$, calcium $\left(\mathrm{Ca}^{2+}, \mathrm{mg} \mathrm{l}^{-1}\right)$, magnesium $\left(\mathrm{Mg}^{2+}, \mathrm{mg} \mathrm{l}^{-1}\right)$, total nitrogen $\left(\mathrm{TN}, \mathrm{mg} \mathrm{l}^{-1}\right)$, nitrate $\left(\mathrm{NO}_{3}{ }^{-}, \mathrm{mg} \mathrm{l}^{-1}\right)$, ammonium $\left(\mathrm{NH}_{4}{ }^{+}, \mathrm{mg} \mathrm{l}^{-1}\right)$, total phosphorous (TP, $\mathrm{mg} \mathrm{l}^{-1}$ ), orthophosphate $\left(\mathrm{PO}_{4}{ }^{3-}\right.$, $\mathrm{mg}^{-1}$ ), biochemical oxygen demand (BOD, $\mathrm{mg} \mathrm{O}_{2}$ $\left.1^{-1}\right)$, chlorophyll $a\left(\mathrm{Chl}-a, \mu \mathrm{g}^{-1}\right)$ and total organic carbon (TOC, $\mathrm{mg} \mathrm{l}^{-1}$ ). Physical and chemical analyses of water were conducted in accordance with APHA-AWWA-WEF guidelines (1999). The Trophic State Index (TSI) of the lakes was calculated based on total phosphorus (TSI TP), chlorophyll $a$ (TSI Chl- $a$ ), and Secchi disk transparency (TSI SDT) (Carlson, 1977).

\section{Statistical analyses}

The overall differences in the physical and chemical parameters of water and zooplankton parameters across the studied lakes were determined by nonparametric analyses (Statistica 13.0 for Windows, Statsoft, Tulsa). Specifically, we used non-parametric ANOVA and Kruskal-Wallis test to determine statistically significant differences in the physical and chemical parameters of water and the taxonomic and functional structure of zooplankton between lakes $(\mathrm{H}$, $P \leq 0.05)$. Correlations between zooplankton species and environmental variables were calculated with the Spearman's rank-order correlation $(P \leq 0.05)$.

The influence of the trophic, depth, and ion gradients on the spatiotemporal variation in the distribution of zooplankton taxa and functional groups was determined with the use of multivariate ordination techniques in CANOCO 4.56 software (ter Braak \& Śmilauer, 2002). Two analyses that differed in the range of data were performed. The first analysis evaluated the influence of the trophic gradient, productivity and ions on the zooplankton in the polymictic zone of lakes (epilimnion). The abundance of zooplankton species were $\log (x+1)$ transformed, and taxa with minimum $2 \%$ relative abundance in a given lake were used in further analysis. A preliminary detrended correspondence analysis (DCA with detrending by segments) was performed to estimate gradient length in standard deviation (SD) units. Gradient length was shorter than 3 (2.475 SD), and subsequent numerical analyses involved techniques that were based on the underlying linear speciesresponse model (Jongman et al., 1995). Variance inflation factors (VIF) were applied to identify correlated variables, and the results were used to eliminate selected variables from further analyses. A total of eighteen environmental variables were included in preliminary analyses, and six of those were eliminated. SDT, $\mathrm{PO}_{4}{ }^{3-}, \mathrm{NO}_{3}{ }^{-}, \mathrm{EC}, \mathrm{Ca}^{2+}$ and color were not included in the analyzed dataset because these parameters were strongly correlated with the selected variables.

The second analysis examined the effects of depth (temperature, oxygen concentration and density of water) on the zooplankton in the stratified Lake WLA, and species with a minimum relative abundance of $1 \%$ were used in the multivariate ordination analysis. A total of seven environmental variables were included in analyses.

The significance of canonical axes and environmental variables to explain the variance of the community was tested using Monte Carlo simulations with 499 permutations. The forward selection option in CANOCO was then used to identify environmental variables that significantly influenced the distribution of zooplankton.

\section{Results}

Taxonomic and functional structure of zooplankton

A total of 67 zooplankton taxa were identified, including 35 Rotifera, 9 Copepoda, 13 Cladocera. In all of the lakes, rotifers were the dominant taxa that accounted for $41.6 \%$ (JAN), 55.0\% (PRZ), and 84.7\% (WLA) of total zooplankton abundance. The dominant species were Polyarthra longiremis Carlin, 1943 (RAP; 26-42\%), P. vulgaris Carlin, 1943 (RAP; 5-27\%), Keratella cochlearis (Gosse, 1851) (SMF; 12-44\%), Keratella quadrata (Müller, 1786) (LMF; $31 \%$ in PRZ), and Ascomorpha ovalis (Bergendal, 1892) (RAP; 7-11\%). Crustacea were represented mainly by the copepod larval stages of nauplii (SMF; 8-32\%) and copepodites (LMF; 2-15\%), as well as Bosmina longirostris (Müller, 1776) (LMF; 4-7\%), Daphnia cucullata Sars, 1862 (LMF; 8\% in PRZ), Ceriodaphnia quadrangula (Müller, 1785) (LMF; $20 \%$ in JAN) and Eudiaptomus graciloides (Lilljeborg, 1888) (STA/SUS; $13 \%$ in JAN; Table 2). The relative abundances of Cladocera ranged from $2.5 \%$ 
Table 2 Taxonomic and trophic structure of zooplankton based on dominant and frequent taxa in each lake (mean \pm SD)

\begin{tabular}{|c|c|c|c|c|c|c|c|c|}
\hline \multirow[t]{2}{*}{ TAXA } & \multicolumn{2}{|c|}{ Group } & \multicolumn{2}{|l|}{ JAN } & \multicolumn{2}{|l|}{ PRZ } & \multicolumn{2}{|l|}{ WLA } \\
\hline & Tro & Eco & $\tilde{x}$ & $\pm \mathrm{SD}$ & $\tilde{x}$ & $\pm \mathrm{SD}$ & $\tilde{x}$ & $\pm \mathrm{SD}$ \\
\hline Rotifera (ind. $\mathrm{I}^{-1}$ ) & & & 340 & 185 & 2375 & 3019 & 1151 & 1,447 \\
\hline Anuraeopsis fissa (Gosse, 1851) & SMF & $e u$ & & & 2 & 4 & & \\
\hline $\begin{array}{l}\text { Ascomorpha ovalis (Bergendal, } \\
\text { 1892) }\end{array}$ & RAP & $e u$ & 25 & 35 & 9 & 18 & $124 * *$ & 353 \\
\hline $\begin{array}{l}\text { Asplanchna priodonta Gosse, } \\
1850\end{array}$ & RAP & $e u$ & & & 73 & 149 & $<1$ & 1 \\
\hline $\begin{array}{l}\text { Brachionus angularis Gosse, } \\
1851\end{array}$ & LMF & $e u$ & & & 116 & 327 & $<1$ & 1 \\
\hline $\begin{array}{l}\text { Brachionus calyciflorus } \\
\text { Pallas, } 1766\end{array}$ & LMF & $e u$ & & & 2 & 4 & & \\
\hline $\begin{array}{l}\text { Colurella colurus (Ehrenberg, } \\
\text { 1830) }\end{array}$ & SMF & ps & & & & & $<1$ & 1 \\
\hline $\begin{array}{l}\text { Conochilus unicornis Rousselet, } \\
1832\end{array}$ & SMF & $e u$ & 38 & 75 & 101 & 273 & $<1$ & 1 \\
\hline $\begin{array}{l}\text { Filinia longiseta (Ehrenberg, } \\
\text { 1834) }\end{array}$ & SMF & $e u$ & & & 40 & 113 & 1 & 1 \\
\hline Gastropus stylifer Imhof, 1891 & RAP & $e u$ & 5 & 9 & $<1$ & 1 & 28 & 44 \\
\hline Hexarthra mira (Hudson, 1871) & SMF & $e u$ & 7 & 9 & & & $<1$ & 1 \\
\hline $\begin{array}{l}\text { Kellicottia longispina (Kellicott, } \\
\text { 1879) }\end{array}$ & SMF & $e u$ & 2 & 4 & 3 & 5 & & \\
\hline $\begin{array}{l}\text { Keratella cochlearis (Gosse, } \\
\text { 1851) }\end{array}$ & SMF & $e u$ & $149 * *$ & 94 & $281 *$ & 442 & $185^{* *}$ & 243 \\
\hline $\begin{array}{l}\text { Keratella quadrata (Müller, } \\
\text { 1786) }\end{array}$ & LMF & $e u$ & $<1$ & 1 & $732 * *$ & 1507 & 1 & 1 \\
\hline Keratella tecta (Gosse, 1851) & SMF & $e u$ & $<1$ & 1 & 1 & 4 & 1 & 2 \\
\hline $\begin{array}{l}\text { Keratella valga (Ehrenberg, } \\
\text { 1834) }\end{array}$ & SMF & $e u$ & & & & & $<1$ & 1 \\
\hline Lecane spp. & SMF & $\begin{array}{l}p s / \\
e u\end{array}$ & 1 & 1 & $<1$ & 1 & $<1$ & 1 \\
\hline Lepadella ovalis (Müller, 1786) & SMF & ps & $<1$ & 1 & 1 & 2 & $<1$ & 1 \\
\hline Pleosoma hudsoni (Imhof, 1891) & RAP & $e u$ & 1 & 4 & & & & \\
\hline $\begin{array}{l}\text { Polyarthra longiremis Carlin, } \\
1943\end{array}$ & RAP & $\begin{aligned} e u / \\
l i\end{aligned}$ & $87 * *$ & 101 & $626^{* *}$ & 1177 & $479 * *$ & 344 \\
\hline Polyarthra vulgaris Carlin, 1943 & RAP & $\begin{aligned} e u / \\
l i\end{aligned}$ & 18 & 52 & $171 *$ & 227 & $330 * *$ & 444 \\
\hline Pompholyx sulcata Hudson, 1885 & SMF & $e u$ & $<1$ & 1 & 36 & 87 & & \\
\hline Synchaeta spp. & RAP & $\begin{aligned} e u / \\
l i\end{aligned}$ & 2 & 4 & 13 & 23 & 2 & 5 \\
\hline $\begin{array}{l}\text { Testudinella parva (Ternetz, } \\
\text { 1892) }\end{array}$ & SMF & $\begin{aligned} e u / \\
l i\end{aligned}$ & & & 1 & 1 & & \\
\hline $\begin{array}{l}\text { Trichocerca pusilla (Lauterborn, } \\
\text { 1898) }\end{array}$ & RAP & $\begin{aligned} e u / \\
l i\end{aligned}$ & $<1$ & 1 & 7 & 16 & & \\
\hline $\begin{array}{l}\text { Trichocerca similis (Wierzejski, } \\
\text { 1893) }\end{array}$ & RAP & $\begin{aligned} e u / \\
l i\end{aligned}$ & 5 & 10 & 160 & 380 & $<1$ & 1 \\
\hline $\begin{array}{l}\text { Trichotria pocillum (Müller, } \\
\text { 1776) }\end{array}$ & SMF & $e u$ & $<1$ & 1 & & & $<1$ & 1 \\
\hline Cladocera (ind. $\mathrm{I}^{-1}$ ) & & & 131 & 82 & 412 & 404 & 38 & 93 \\
\hline
\end{tabular}


Table 2 continued

\begin{tabular}{|c|c|c|c|c|c|c|c|c|}
\hline \multirow[t]{2}{*}{ TAXA } & \multicolumn{2}{|l|}{ Group } & \multicolumn{2}{|l|}{ JAN } & \multicolumn{2}{|l|}{ PRZ } & \multicolumn{2}{|l|}{ WLA } \\
\hline & Tro & Eco & $\tilde{x}$ & $\pm \mathrm{SD}$ & $\tilde{x}$ & $\pm \mathrm{SD}$ & $\tilde{x}$ & $\pm \mathrm{SD}$ \\
\hline Acroperus harpae (Baird, 1835) & LMF & $l i$ & $<1$ & 1 & & & & \\
\hline Alona spp. & LMF & $l i$ & $<1$ & 1 & & & $<1$ & 1 \\
\hline $\begin{array}{l}\text { Bosmina longirostris (Müller, } \\
\text { 1776) }\end{array}$ & LMF & $e u$ & 15 & 29 & $166^{*}$ & 403 & $<1$ & 1 \\
\hline $\begin{array}{l}\text { Ceriodaphnia quadrangula } \\
\text { (Müller, 1785) }\end{array}$ & LMF & $e u$ & $69 *$ & 57 & 1 & 2 & $<1$ & 1 \\
\hline $\begin{array}{l}\text { Chydorus sphaericus (Müller, } \\
1785 \text { ) }\end{array}$ & LMF & $e u$ & $<1$ & 1 & 12 & 33 & $<1$ & 1 \\
\hline Daphnia cucullata Sars, 1862 & LMF & $e u$ & & & $179 *$ & 211 & & \\
\hline $\begin{array}{l}\text { Diaphanosoma brachyurum } \\
\text { (Liévin, 1848) }\end{array}$ & LMF & li/ & 8 & 16 & 22 & 23 & 38 & 93 \\
\hline $\begin{array}{l}\text { Eubosmina longicornis kessleri } \\
\quad \text { (Uljanin, 1874) }\end{array}$ & LMF & $e u$ & 31 & 43 & 14 & 39 & & \\
\hline Moina sp. & LMF & $l i$ & 1 & 2 & & & & \\
\hline $\begin{array}{l}\text { Pleuroxus trigonellus (Müller, } \\
\text { 1776) }\end{array}$ & LMF & $l i$ & & & $<1$ & 1 & & \\
\hline $\begin{array}{l}\text { Scapholeberis mucronata } \\
\quad \text { (Müller, 1776) }\end{array}$ & LMF & $l i$ & & & & & $<1$ & 1 \\
\hline Cladocera juv. & LMF & li/ & 7 & 9 & 18 & 26 & $<1$ & 1 \\
\hline Copepoda (ind. $\mathrm{l}^{-1}$ ) & & & 213 & 124 & 572 & 270 & 141 & 156 \\
\hline Acanthocyclops sp. & RAP & $e u$ & & & 8 & 22 & & \\
\hline Cyclops spp. & RAP & $e u$ & & & 8 & 15 & 17 & 26 \\
\hline $\begin{array}{l}\text { Eudiaptomus graciloides } \\
\text { (Lilljeborg, 1888) }\end{array}$ & $\begin{array}{l}\text { STA/ } \\
\text { SUS }\end{array}$ & $e u$ & $43 *$ & 29 & 16 & 15 & 1 & 1 \\
\hline Harpacticoida & RAP & ps & & & $<1$ & 1 & & \\
\hline Macrocyclops sp. & RAP & $l i$ & & & 17 & 39 & 1 & 2 \\
\hline $\begin{array}{l}\text { Thermocyclops crassus (Fischer, } \\
\text { 1853) }\end{array}$ & RAP & $e u$ & 9 & 11 & 30 & 36 & 3 & 6 \\
\hline copepodites & $\mathrm{LMF}$ & $e u$ & $52 *$ & 32 & 124 & 76 & 25 & 35 \\
\hline nauplii & SMF & $e u$ & $109 * *$ & 83 & $369 * *$ & 198 & 94 & 83 \\
\hline Other groups (ind. $\mathbf{I}^{-1}$ ) & & & 187 & 259 & 272 & 315 & 9 & 18 \\
\hline $\begin{array}{l}\text { Protozoa ( } 99 \% \text { Codonella } \\
\text { cratera) }\end{array}$ & & $e u$ & $146^{* *}$ & 207 & $268 *$ & 308 & 6 & 14 \\
\hline $\begin{array}{l}\text { Bivalvia (Dreissena polymorpha } \\
\text { larvae) }\end{array}$ & & $e u$ & $41 *$ & 58 & 4 & 7 & 3 & 4 \\
\hline $\begin{array}{l}\text { Abundance of zooplankton } \\
\left.\text { (ind. } 1^{-1}\right)\end{array}$ & & & 871 & 513 & 3631 & 3,330 & 1,339 & 1,714 \\
\hline Rotifera $(\%)$ & & & 41.6 & 19.0 & 55.0 & 20.8 & 84.7 & 9.7 \\
\hline Cladocera $(\%)$ & & & 15.9 & 9.4 & 10.8 & 11.8 & 2.5 & 5.4 \\
\hline Copepoda $(\%)$ & & & 26.6 & 8.9 & 24.4 & 13.4 & 11.7 & 5.7 \\
\hline Other groups $(\%)$ & & & 15.9 & 15.1 & 9.8 & 11.0 & 1.0 & 1.1 \\
\hline $\begin{array}{l}\text { Biomass of zooplankton (mg } \\
\left.\mathbf{l}^{-1}\right)^{\dagger}\end{array}$ & & & 3.20 & 1.96 & 13.58 & 13.10 & 4.98 & 7.85 \\
\hline $\operatorname{SMF}(\%)$ & & & 3.1 & 2.2 & 3.8 & 3.5 & 3.2 & 2.1 \\
\hline $\operatorname{LMF}(\%)$ & & & 58.2 & 12.0 & 78.9 & 11.4 & 36.4 & 28.5 \\
\hline $\operatorname{RAP}(\%)$ & & & 5.9 & 8.9 & 13.0 & 8.2 & 58.6 & 27.2 \\
\hline
\end{tabular}


Table 2 continued

\begin{tabular}{|c|c|c|c|c|c|c|c|c|}
\hline \multirow[t]{2}{*}{ TAXA } & \multicolumn{2}{|c|}{ Group } & \multicolumn{2}{|l|}{ JAN } & \multicolumn{2}{|l|}{ PRZ } & \multicolumn{2}{|l|}{ WLA } \\
\hline & Tro & Eco & $\tilde{x}$ & $\pm \mathrm{SD}$ & $\tilde{x}$ & $\pm \mathrm{SD}$ & $\tilde{x}$ & $\pm \mathrm{SD}$ \\
\hline STA/SUS (\%) & & & 32.8 & 13.2 & 4.3 & 7.7 & 1.8 & 2.0 \\
\hline Number of species (ind.) & & & 15 & 4 & 16 & 5 & 12 & 4 \\
\hline Pielou's eveness index, $J$ ' & & & 0.639 & 0.170 & 0.611 & 0.125 & 0.419 & 0.186 \\
\hline Shannon's biodiversity index, $H^{\prime}$ & & & 1.65 & 0.34 & 1.66 & 0.39 & 1.06 & 0.51 \\
\hline Trophic groups ratio, GR' & & & -0.553 & 0.166 & -0.698 & 0.179 & 0.278 & 0.425 \\
\hline
\end{tabular}

Bold - abundance of the main taxonomic groups of zooplankton and total abundance and biomass of zooplankton

Denotations: $e u$ eurytopic, $p s$ psammonic, $l i$ littoral taxa; $S M F$ small microphagous, $L M F$ large microphagous, $R A P$ raptorials. ${ }^{\dagger}$ Total biomass of zooplankton without Bivalvia larvae, ** - eudominant $(\geq 10 \%)$, * - dominant $(5-9.9 \%)$

Table 3 Water quality parameters of the studied lakes (mean $\pm \mathrm{SD})$

Denotations: SDT Secchi disk transparency, $D O$ dissolved oxygen, $B O D$ biological oxygen demand, $E C$ electrical conductivity, SUS total suspension, $T H$ total hardness, $M C$ alkalinity, Chl$a$ chlorophyll a, TP total phosphorus, $T N$ total nitrogen, TOC total organic carbon. Values with the different superscripts are significantly different among reservoirs by nonparametric Kruskal-Wallis test (ANOVA, $P<0.05$ )

\begin{tabular}{|c|c|c|c|}
\hline & JAN & PRZ & WLA \\
\hline Temperature ( $\mathrm{C}$ ) & $17.6^{\mathrm{ab}} \pm 3.8$ & $18.2^{\mathrm{a}} \pm 4.5$ & $14.4^{\mathrm{b}} \pm 3.4$ \\
\hline $\mathrm{pH}$ & $7.78 \pm 0.47$ & $7.78 \pm 0.55$ & $7.8 \pm 0.45$ \\
\hline SDT (m) & $6.7^{\mathrm{a}} \pm 0.9$ & $1.9^{\mathrm{b}} \pm 1.3$ & $3.5^{\mathrm{b}} \pm 0.7$ \\
\hline Color (Hazen) & $6.2^{\mathrm{ab}} \pm 0.9$ & $22.2^{\mathrm{a}} \pm 2.4$ & $5.6^{\mathrm{b}} \pm 1.2$ \\
\hline Turbidity (NTU) & $3^{\mathrm{a}} \pm 1$ & $12^{\mathrm{b}} \pm 4$ & $3^{\mathrm{a}} \pm 1$ \\
\hline $\mathrm{DO}\left(\mathrm{mg} \mathrm{l}^{-1}\right)$ & $10.65 \pm 1.52$ & $8.80 \pm 1.41$ & $9.50 \pm 0.88$ \\
\hline DO $(\%)$ & $112.4^{\mathrm{a}} \pm 13.8$ & $97.5^{\mathrm{ab}} \pm 17.0$ & $93.2^{\mathrm{b}} \pm 8.4$ \\
\hline $\mathrm{BOD}\left(\mathrm{mg} \mathrm{O}_{2} 1^{-1}\right)$ & $0.78 \pm 0.69$ & $3.47 \pm 4.02$ & $1.06 \pm 0.64$ \\
\hline $\mathrm{EC}\left(\mu \mathrm{S} \mathrm{cm}{ }^{-1}\right)$ & $660^{\mathrm{a}} \pm 69$ & $353^{\mathrm{b}} \pm 37$ & $482^{\mathrm{ab}} \pm 44$ \\
\hline SUS $\left(\mathrm{mg} \mathrm{l}^{-1}\right)$ & $1.67 \pm 0.96$ & $4.96 \pm 6.06$ & $1.78 \pm 2.71$ \\
\hline $\mathrm{Cl}^{-}\left(\mathrm{mg} \mathrm{l}^{-1}\right)$ & $51^{\mathrm{a}} \pm 14$ & $21^{\mathrm{ab}} \pm 5$ & $17^{\mathrm{b}} \pm 3$ \\
\hline $\mathrm{Ca}^{2+}\left(\mathrm{mg} \mathrm{l}^{-1}\right)$ & $84.2^{\mathrm{a}} \pm 20.2$ & $44.6^{\mathrm{b}} \pm 6.5$ & $81.4^{\mathrm{a}} \pm 8.2$ \\
\hline $\mathrm{Mg}^{2+}\left(\mathrm{mg} \mathrm{l}^{-1}\right)$ & $14.4 \pm 0.8$ & $10.7 \pm 4.6$ & $17.2 \pm 9.5$ \\
\hline $\mathrm{TH}\left(\mathrm{mval}^{-1}\right)$ & $5.5^{\mathrm{a}} \pm 0.94$ & $2.98^{\mathrm{b}} \pm 0.35$ & $5.38^{\mathrm{a}} \pm 0.31$ \\
\hline $\mathrm{MC}\left(\mathrm{mval} \mathrm{l}^{-1}\right)$ & $3.3 \pm 1.3$ & $2.9 \pm 0.3$ & $3.1 \pm 0.4$ \\
\hline Chl- $a\left(\mu \mathrm{g}^{-1}\right)$ & $2.81^{\mathrm{ab}} \pm 3.92$ & $17.67^{\mathrm{a}} \pm 21.35$ & $1.81^{\mathrm{b}} \pm 1.25$ \\
\hline $\mathrm{PO}_{4}{ }^{3-}\left(\mathrm{mg} \mathrm{l}^{-1}\right)$ & $0.010 \pm 0.012$ & $0.031 \pm 0.032$ & $0.013 \pm 0.011$ \\
\hline $\mathrm{TP}\left(\mathrm{mg} \mathrm{l}^{-1}\right)$ & $0.069^{\mathrm{ab}} \pm 0.023$ & $0.149^{\mathrm{a}} \pm 0.068$ & $0.078^{\mathrm{b}} \pm 0.025$ \\
\hline $\mathrm{NH}_{4}^{+}\left(\mathrm{mg} \mathrm{l}^{-1}\right)$ & $0.031^{\mathrm{a}} \pm 0.025$ & $0.352^{b} \pm 0.594$ & $0.042^{\mathrm{a}} \pm 0.046$ \\
\hline $\mathrm{NO}_{3}^{-}\left(\mathrm{mg} \mathrm{l}^{-1}\right)$ & $0.098^{\mathrm{a}} \pm 0.038$ & $0.179^{\mathrm{b}} \pm 0.095$ & $0.101^{\mathrm{ab}} \pm 0.048$ \\
\hline $\mathrm{TN}\left(\mathrm{mg} \mathrm{l}^{-1}\right)$ & $0.301^{\mathrm{ab}} \pm 0.047$ & $1.07^{\mathrm{a}} \pm 0.749$ & $0.105^{\mathrm{b}} \pm 0.042$ \\
\hline TOC $\left(\mathrm{mg} \mathrm{l}^{-1}\right)$ & $6.31 \pm 1.22$ & $7.73 \pm 1.71$ & $2.98 \pm 0.43$ \\
\hline
\end{tabular}

(WLA) to $15.9 \%$ (JAN), and Copepoda-from $11.7 \%$ (WLA) to $26.6 \%$ (JAN). The number of species, zooplankton abundance and biomass were highest in PRZ (12-26, 219-11,156 ind. $1^{-1}$ and $\left.3.48-37.38 \mathrm{mg}^{-1}\right)$ and lowest in WLA (11-22 and 195-2,721 ind. $1^{-1}$ and 0.39-25.41 mg $1^{-1}$; Table 3; Fig. S2). The zooplankton of JAN and PRZ were highly diverse $\left(H^{\prime}\right.$ mean $=1.65$ and $1.66 ; J_{\text {mean- }}^{\prime}$ $=0.639$ and 0.611 , respectively; Table 2).

A comparison of zooplankton structure based on Sorensen's coefficient revealed qualitative differences in each lake across seasons (Fig. 2). In a dendrogram based on the values of the Bray-Curtis dissimilarity index, the zooplankton groups in the studied lakes 


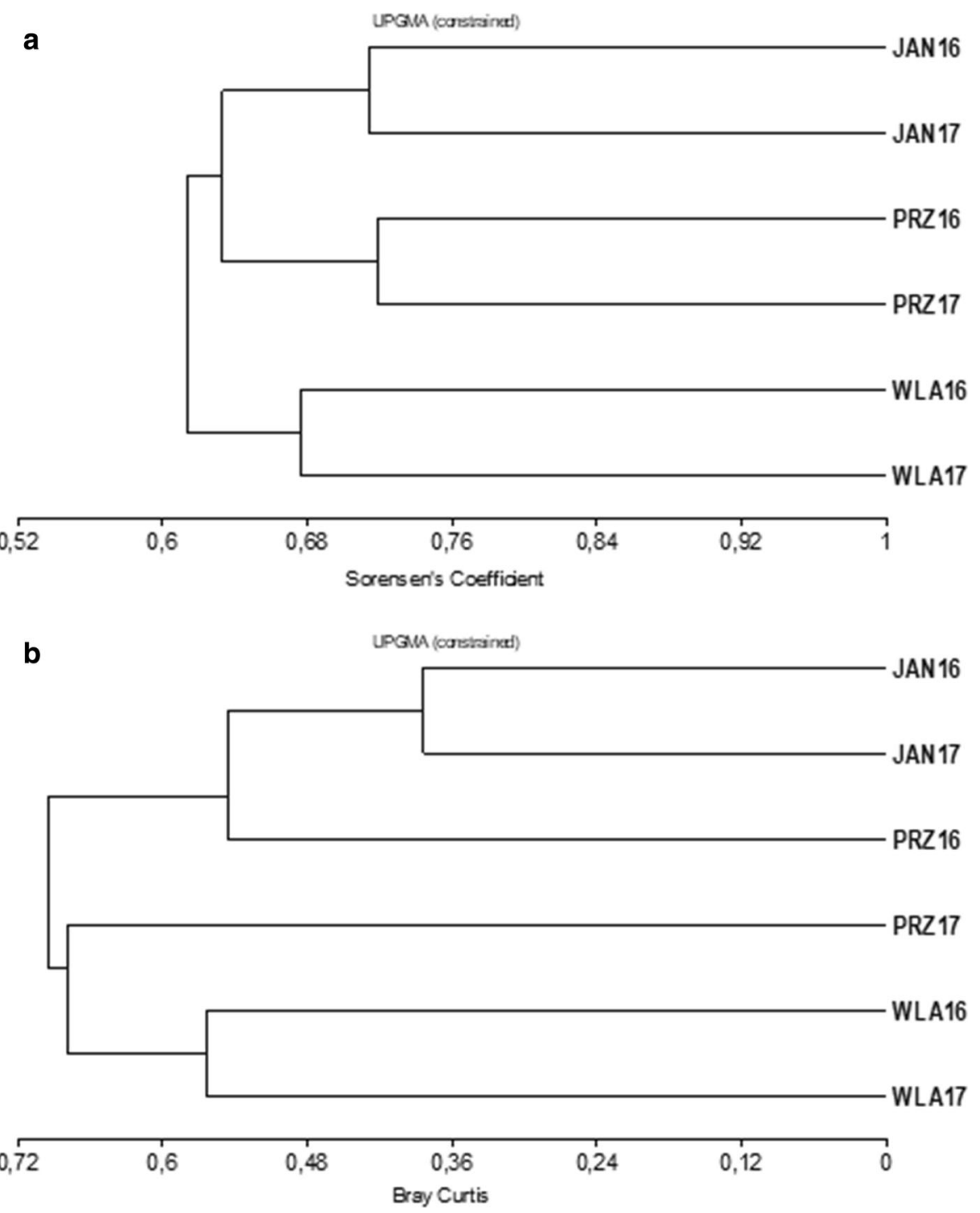

Fig. 2 Dendrograms comparing zooplankton communities of studied lakes JAN, PRZ and WLA in 2016-2017, based on (a) Sorensen's similarity coefficient, and (b) Bray-Curtis dissimilarity index

were divided into two clusters, revealing the differences between the seasons of 2016 and 2017 in PRZ. The structure of zooplankton in PRZ was characterized by $57 \%$ similarity to JAN in 2017 , and by $32 \%$ similarity to WLA in 2017. The zooplankton community in JAN was most stable and similar (63\%) during the entire study (Fig. 2).

The zooplankton trophic groups were most abundant in PRZ lake, in order: SMF (0.03-0.32 $\left.\mathrm{mg} \mathrm{l}^{-1}\right)$, LMF (1.81-31.28 $\left.\mathrm{mg} \mathrm{l}^{-1}\right)$ and raptorial (0.29-9.43 $\left.\mathrm{mg} \mathrm{l}^{-1}\right)$. The biomass of STA/SUS was highest in JAN $\left(0.12-3.48 \mathrm{mg} \mathrm{l}^{-1}\right.$; Fig. 3$)$. The differences in the mean biomass of SMF, LMF and RAP functional groups in the lakes were statistically significant $(P \leq 0.05$; Fig. 3$)$. Seasonal variations in GR' values ranged from -0.392 to -0.929 in PRZ and from -0.222 to -0.732 in JAN (Fig. 4). Large microphagous feeders in lakes PRZ and LMF and STA/SUS groups in JAN had the highest proportions of total zooplankton biomass during the entire study (Supplementary Fig. S2). The broadest range of GR' values was noted in WLA between the epilimnion in August ( -0.923$)$ and the hypolimnion in October (0.985) 2016 (Fig. 4), which resulted from temporal 

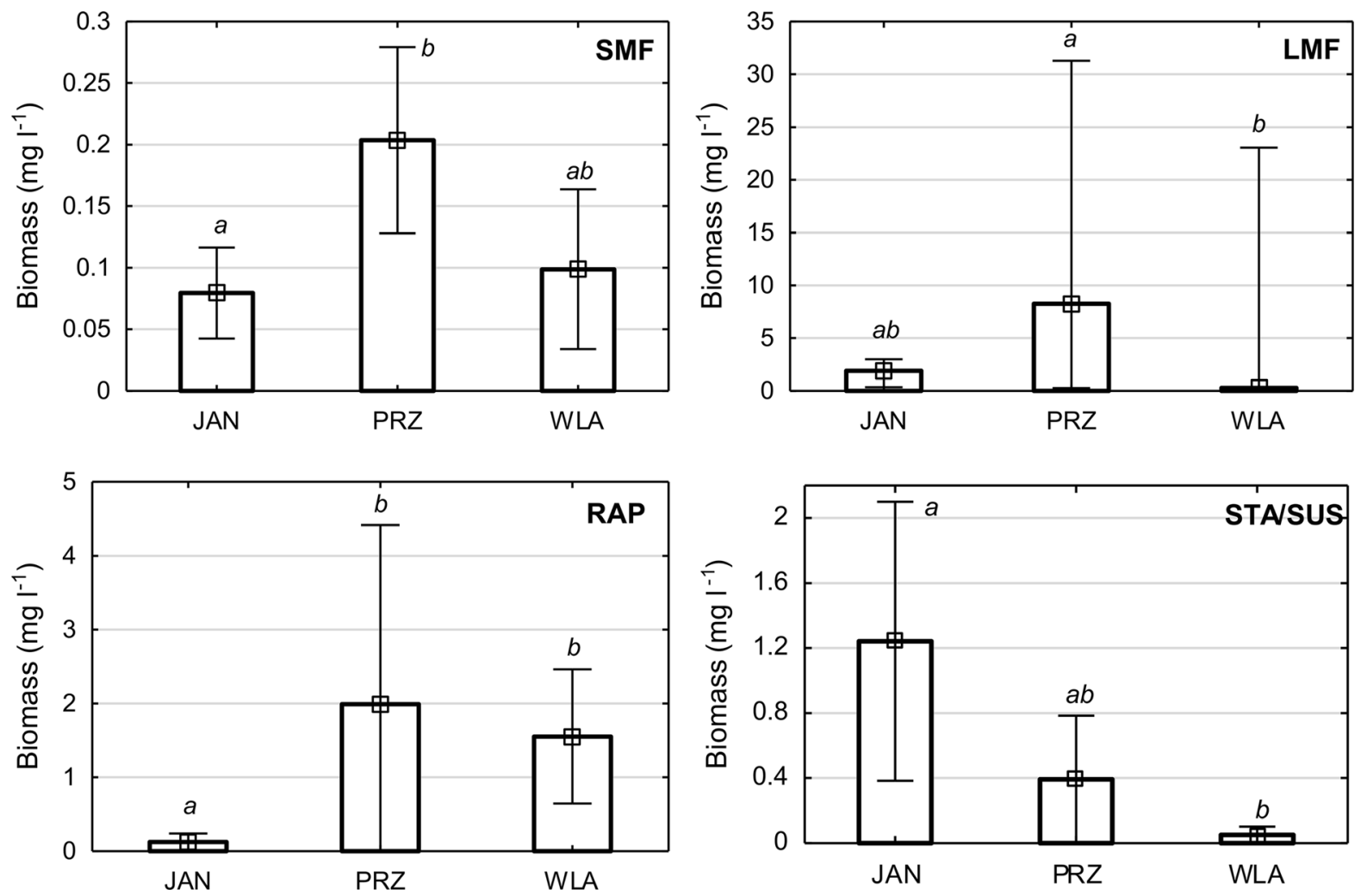

Fig. 3 Mean biomass of zooplankton functional groups $\left(\mathrm{mg}^{-1}\right)$ in each reservoir. Small square: mean value, rectangle: \pm standard error, swirls: $\pm \mathrm{SD}$

and spatial variation in the dominance of LMF and RAP groups (Supplementary Fig. S2).

The mean zooplankton grazing rates ranged from $18.9 \%$ day $^{-1}$ (JAN) to $78.8 \%$ day $^{-1}$ (PRZ), but only remained stable during both years of the study in JAN. The grazing rate in Lake WLA decreased from $57 \%$ in 2016 to $7 \%$ day $^{-1}$ in 2017, and it increased from $18 \%$ to $128 \%$ day $^{-1}$ in PRZ in the corresponding years. SMF group was characterized by the lowest grazing rate which ranged from $1 \%$ (WLA) to $6 \%$ day $^{-1}$ (PRZ) on average (Fig. 5). The abundance and total grazing efficiency of the LMF group peaked in PRZ in 2017 (1453 ind. $1^{-1}$ and $419 \%$ day $^{-1}$ on average; Fig. 5) when the lake was massively colonized by Keratella quadrata and B. longirostris. In the remaining lakes, the grazing rate of the LMF group ranged from $37 \%$ to $75 \%$ day $^{-1}$ on average, and a minimum value of around $6 \% \mathrm{day}^{-1}$ was noted in WLA in 2017. The representative raptorials, A. ovalis and Polyarthra spp., dominated in terms of zooplankton biomass and abundance, mostly in WLA and PRZ (Fig. 5, Table 2).
The mean abundance and grazing rates of $E$. graciloides (STA/SUS) ranged from 1 ind. $1^{-1}$ and $1 \%$ day $^{-1}$ in WLA to 23 ind. $1^{-1}$ and $30 \%$ day $^{-1}$ in JAN, respectively.

Environmental gradient assessment

Significant differences in trophic characteristics were noted between the studied lakes. PRZ was classified as an eutrophic lake based on the values of all chemical parameters (TSI of Chl- $a$, TP, SDT), and as eutrophic based on the values of zooplankton parameters (TSI ZOO) (Table 1). JAN was classified as an oligotrophic lake based on the mean values of TSI Chl- $a$ (32.51) and TSI SDT (32.73), and as a low mesotrophic lake based on the value of TSI ROT (44.48). WLA was classified as an oligo-mesotrophic lake based on the mean values of TSI Chl- $a$ (37.78) and TSI SDT (43.69), and as a low mesotrophic lake based on the values of TSI CRU (43.63) (Table 1). 

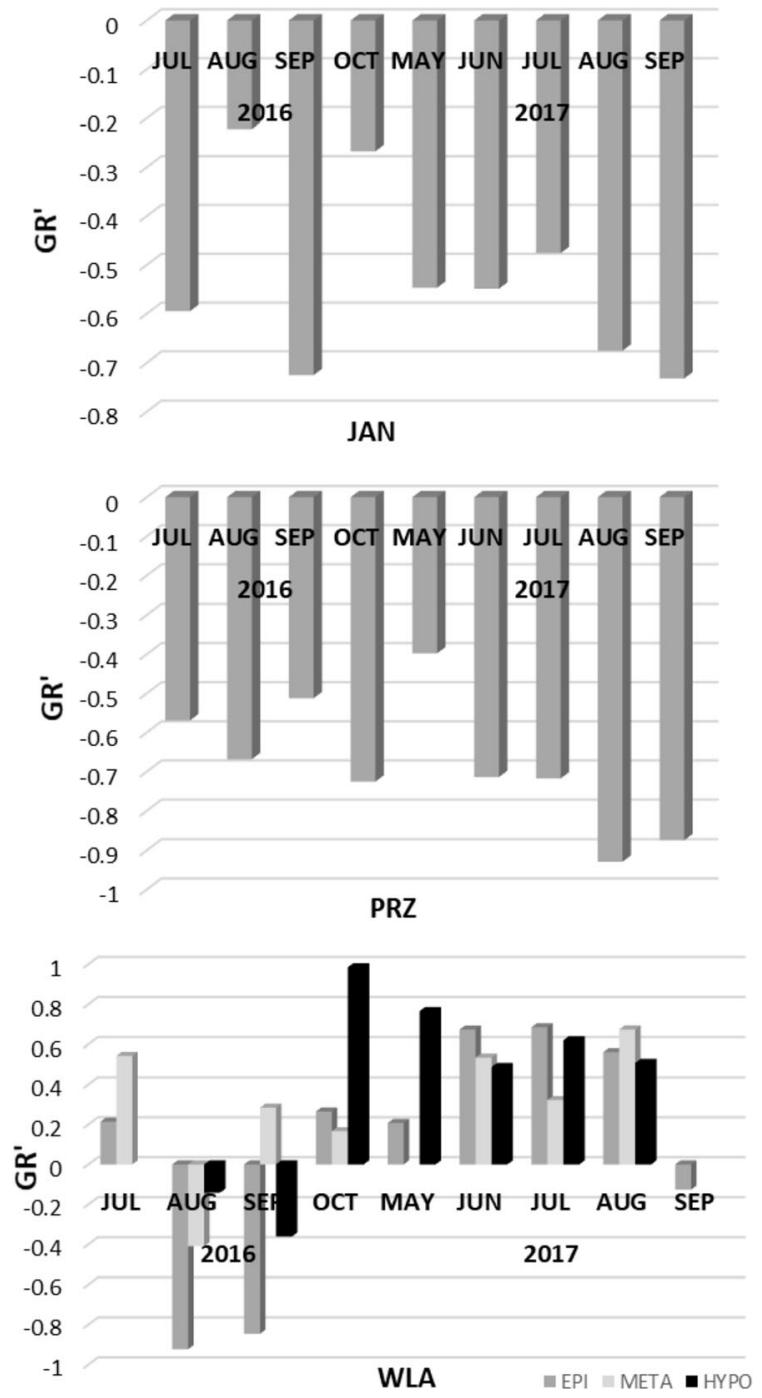

Fig. 4 Temporal variation in the ratio of trophic groups $\left(\mathrm{GR}^{\prime}\right)$ in each lake

The presence of ions (EC, chlorides, $\mathrm{TH}$ and calcium) was the second most differentiating environmental factor in the studied lakes. Ion concentrations were significant higher in JAN $\left(610-760 \mu \mathrm{S} \mathrm{cm}^{-1}\right.$, 32-64 $\mathrm{mg} \mathrm{Cl}^{-} \mathrm{l}^{-1}, 5-6.9 \mathrm{mval}^{-1}$, and 71.4-14.2 $\mathrm{mg}$ $\mathrm{Ca}^{2+} 1^{-1}$, respectively) than in PRZ (309-389 $\mu \mathrm{S}$ $\mathrm{cm}^{-1}, \quad 12-25 \mathrm{mg} \quad \mathrm{Cl}^{-} \quad \mathrm{l}^{-1}, \quad 2.5-3.4 \mathrm{mval} \mathrm{l}^{-1}$, 40-3.6 $\left.\mathrm{mg} \mathrm{Ca}^{2+} \mathrm{l}^{-1}\right)$ and WLA $\left(389-519 \mu \mathrm{S} \mathrm{cm}^{-1}\right.$, $16-26 \mathrm{mg} \mathrm{Cl}^{-} \mathrm{1}^{-1}, 4.7-5.5 \mathrm{mval}^{-1}, 64.2-84.1 \mathrm{mg}$ $\mathrm{Ca}^{2+} 1^{-1}$; Table 3).

In shallow polymictic lakes JAN and PRZ water temperature changed in a uniform manner between the surface and the bottom under the influence of seasonal changes in air temperature. In the stratified WLA lake, thermal stratification and oxygen distribution also changed with depth (Supplementary Fig. S1). During the summer stagnation period, a thermocline was observed between the depth of $7 \mathrm{~m}$ and $9 \mathrm{~m}$, and temperature and oxygen saturation gradients between the epilimnion and the hypolimnion were determined at $13.9^{\circ} \mathrm{C}$ and $2.3 \mathrm{mg} \mathrm{O}_{2} \mathrm{l}^{-1}$, respectively. Metalimnetic oxygen maxima with a positive heterograde oxygen curve (11.3 $\mathrm{mg} \mathrm{O}_{2} \mathrm{l}^{-1}, 107 \%$ saturation) were observed in July 2017 (Supplementary Fig. S1).

Primary predictors of zooplankton variability

In a redundancy analysis of the polymictic layer, five of the 12 environmental variables (TN, TH, SUS, Chl$a$ and BOD) explained $67.4 \%(P<0.05)$ of total variance in zooplankton data. Forward selection of explanatory variables demonstrated that the best predictors zooplankton assemblage were TN (16\%, $P=0.002)$, followed by TH $(8 \%, P=0.004)$, SUS $(8 \%, P=0.010)$, Chl- $a(8 \%, P=0.026)$ and BOD (5\%, $P=0.046$; Supplementary Table S1). The Monte Carlo permutation test revealed significant correlations between species and environmental factors along the first two RDA axes $(F=2.415, P<0.002)$. The correlation coefficients and the explained variation for axis 1 and axis 2 were determined at 0.97 and 0.912 , and $21.5 \%$ and $15.5 \%$, respectively (Supplementary Table S2). On the first axis, the highest correlation between environmental variables and sample location was determined for $\mathrm{TN}(r=0.79)$. Axis 2 was correlated with Chl- $a(r=0.36)$.

All predictors of zooplankton variability, indicating water trophy (TN, TP), productivity (Chl- $a$, suspension) and organic matter content (BOD, TOC) were correlated in PRZ (Fig. 6). The mean values of TN and TP were significant highest in PRZ $(P \leq 0.05$; Table 3), and they were correlated with BOD ( $r=0.64$ and $r=0.51$, respectively; $P<0.05$ ). The concentration of Chl- $a$, turbidity and water color were also significantly higher in PRZ than in JAN and WLA (Table 3). The RDA biplot for species and environmental variables revealed that Bosmina longirostris (LMF) and Asplanchna priodonta Gosse, 1850 (RAP) were positively correlated with TN; Daphnia cucullata (LMF) and Keratella quadrata (LMF) were positively correlated with Chl-a; and Brachionus angularis Gosse, 1851 (SMF), Filinia longiseta 

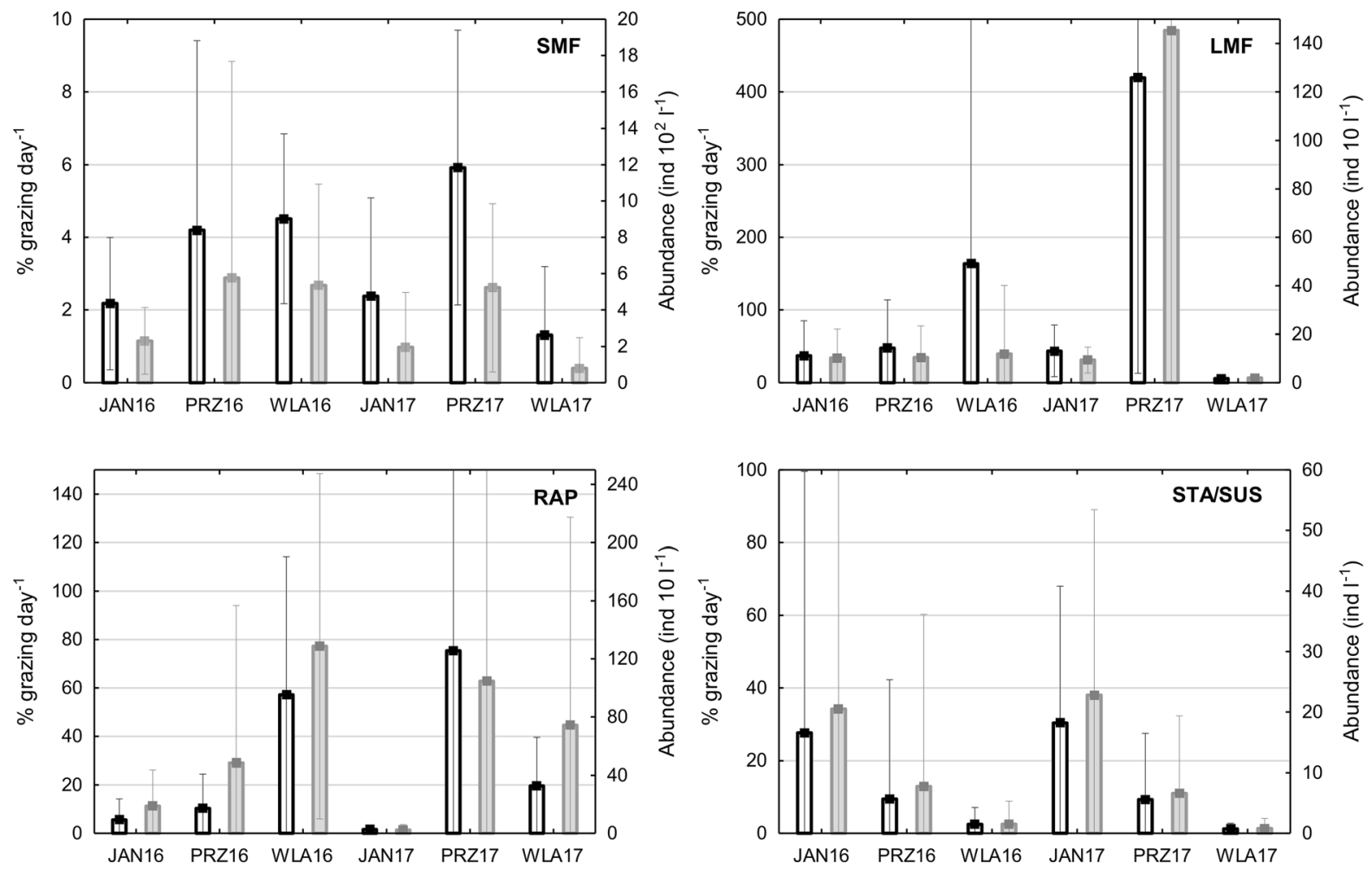

Fig. 5 Variations in the abundance and grazing rate of zooplankton functional groups in each lake and season in 2016-2017. Small square: mean value, rectangle: \pm standard error, swirls: \pm SD

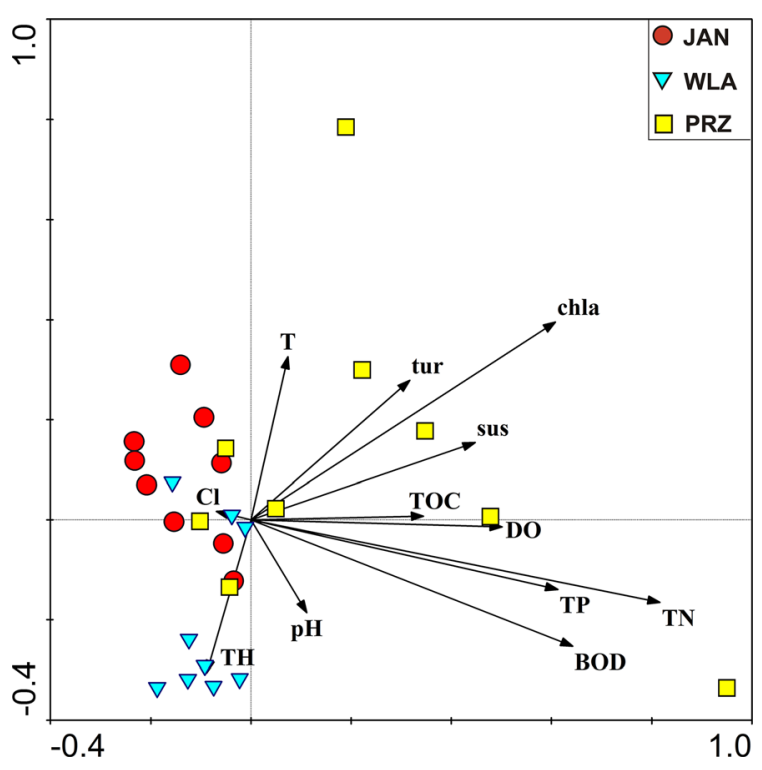

Fig. 6 Redundancy analysis (RDA) ordination plot for environmental variables and samples

(Ehrenberg, 1834) (SMF) and Macrocyclops sp. (RAP) were correlated with BOD (Fig. 7). Total hardness $(8 \%, P=0.004)$ was the second predictor of explanatory variables in zooplankton communities in RDA. Total hardness is an indicator of ion content (in addition to EC, chlorides and calcium), and it was correlated with sampling sites in WLA and JAN (Fig. 6). The differences in the mean values of the above parameters in the lakes were statistically significant $(P \leq 0.05$; Table 3$)$. The RDA biplot for species and environmental variables revealed that most taxa, in particular LMF (Daphnia cucullata, Diaphanosoma brachyurum, Chydorus sphaericus (Müller, 1785), Eubosmina longicornis kessleri (Uljanin, 1874), and Keratella quadrata) and SMF (e.g. Keratella cochlearis, Pompholyx sulcata Hudson, 1885 and nauplii), were negatively correlated with TH. In turn, raptorial species Gastropus stylifer Imhof, 1891, Polyarthra longiremis and Ascomorpha ovalis were positively correlated with $\mathrm{TH}$ and $\mathrm{Cl}$ (Fig. 7).

An RDA relating to the depth gradient of WLA revealed that 3 of the 7 environmental variables (DO, $\%$ DO and EC) explained $59.5 \%(P<0.05)$ of the variation in the distribution of zooplankton taxa and 


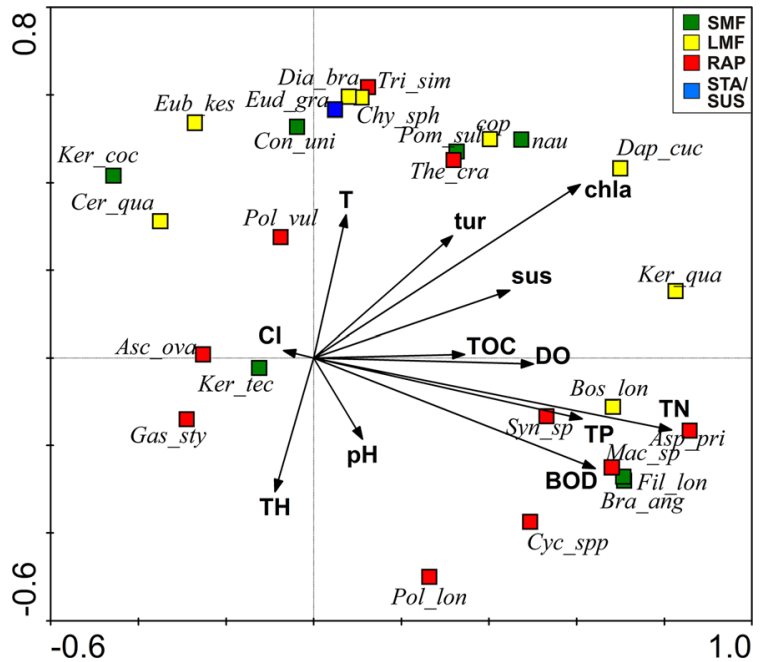

Fig. 7 Redundancy analysis (RDA) ordination plot for species and functional groups of zooplankton and environmental variables in the polymictic layer of the studied lakes. Vectors pointing in the same direction indicate a positive correlation, vectors crossing at right angles indicate a near zero correlation, and vectors pointing in opposite directions denote a negative correlation. Abbreviations: Asc_ova, Ascomorpha ovalis (Bergendal, 1892); Asp_pri, Asplanchna priodonta Gosse, 1850; Bos_lon, Bosmina longirosrtis (Müller, 1776); Bra_ang, Brachionus angularis Gosse, 1851; Cer_qua, Ceriodaphnia quadrangula (Müller, 1785); Chy_sph, Chydorus sphaericus (Müller, 1785); Con_uni, Conochilus unicornis Rousselet, 1832; cop, copepodite of cyclopoids; Cyc_spp, Cyclops spp.; Dap_cuc, Daphnia cucullate Sars, 1862; Dia_bra, Diaphanosoma brachyurum (Liévin, 1848); Eub_kes, Eubosmina longicornis kessleri (Uljanin, 1874); Eud_gra, Eudiaptomus graciloides (Lilljeborg, 1888); Fil_lon, Filinia longiseta (Ehrenberg, 1834); Gas_sty, Gastropus stylifer Imhof, 1891; Ker_coc, Keratella cochlearis (Gosse, 1851); Ker_qua, Keratella quadrata (Müller, 1786); Ker_tec, Keratella tecta (Gosse, 1851); Mac_sp, Macrocyclops sp.; nau, nauplii of cyclopoids; Pol_lon, Polyarthra longiremis Carlin, 1943; Pol_vul, Polyarthra vulgaris Carlin, 1943; Pom_sul, Pompholyx sulcata Hudson, 1885; Syn_spp., Synchaeta spp.; The_cra, Thermocyclops crassus (Fischer, 1853); Tri_spp., Trichocerca spp

functional groups. A forward selection of zooplankton data in RDA demonstrated that oxygen conditions were the best predictors of zooplankton composition (both $14 \%, P=0.03)$, followed by EC $(11 \%$, $P=0.01$; Supplementary Table S3). The speciesenvironment correlations were significant along first two RDA axes (Monte Carlo test, $F=3.152$, $P<0.002)$. Axis 1 accounted for $37.2 \%$ and axis 2 for $9.5 \%$ of the explained variation (Supplementary Table S4). The highest correlation between environmental variables and sampling location was observed

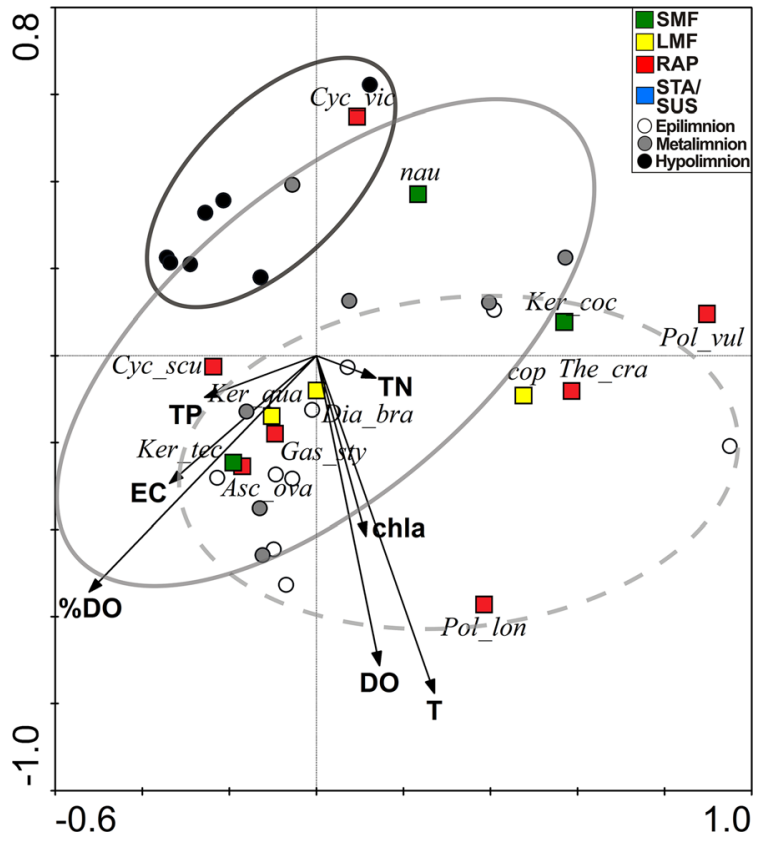

Fig. 8 Redundancy analysis (RDA) ordination plot for zooplankton species and the depth gradient in Lake WLA. Abbreviations: Asc_ova, Ascomorpha ovalis; cop, copepodite of cyclopoids; Cyc_scu, Cyclops scutifer G.O. Sars, 1863; Cyc_vic, Cyclops vicinus Uljanin, 1875; Dia_bra, Diaphanosoma brachyurum; Gas_sty, Gastropus stylifer; Ker_coc, Keratella cochlearis; Ker_qua, Keratella quadrata; Ker_tec, Keratella tecta; nau, nauplii of cyclopoids; Pol_lon, Polyarthra longiremis; Pol_vul, Polyarthra vulgaris; The_cra, Thermocyclops crassus

for $\% \mathrm{DO}(r=-0.46)$ on the first axis. Axis 2 was correlated with $\mathrm{T}(r=-0.50)$. The RDA biplot for species and environmental variables indicated that taxa such as Polyarthra spp. (RAP), Diaphanosoma brachyurum (LMF) and Thermocyclops crassus (Fischer, 1853) (RAP) were positively correlated with epilimnion conditions: temperature, DO and Chl- $a$; whereas Ascomorpha ovalis (RAP), Gastropus stylifer (RAP) and Keratella tecta (Gosse, 1851) (SMF) were positively correlated with \%DO and EC, and were characteristic of the metalimnion. In turn, copepods Cyclops vicinus Uljanin, 1875 (RAP) and nauplii (SMF) were negatively correlated with temperature, oxygen concentration and productivity, and they were identified in the hypolimnion (Fig. 8). 


\section{Discussion}

Our study revealed that the water trophy, depth and ion concentrations influenced the diversity of species and functional structure of zooplankton. The chemical and zooplankton indices confirmed the differences in trophy between the polymictic lakes JAN and PRZ. The high trophic status of PRZ can be attributed to eutrophication that was accelerated by anthropogenic factors. In comparison with the results reported by Marszelewski et al. (2017), the average values of TSI SD, TSI Chl- $a$ and TSI ROT increased by $36 \%, 25 \%$ and $5 \%$, respectively, over a period of only 5 years. As a result, zooplankton abundance increased more than 20 -fold on average, with a high proportion of trophiclevel indicator species, including rotifers Keratella quadrata, Brachionus angularis and Trichocerca similis (Ejsmont-Karabin, 2012) and crustaceans Daphnia cucullata, Bosmina longirostris, Chydorus sphaericus, Diaphanosoma brachyurum and Thermocyclops sp. (Ejsmont-Karabin \& Karabin, 2013). It should be noted that the some functional traits of above-mentioned bioindicator species were previously correlated with water trophy. For example Obertegger \& Manca (2011) and Oh et al. (2017) positively correlated the morphological traits (trophi type) of the genera Keratella and Brachionus and Polyarthra and Trichocerca with high trophic-level parameters and productivity (Chl- $a$ ). In turn, the smaller body size of Cladocera and Copepoda indicator species (Bosmina, Eubosmina, Chydorus, Thermocyclops) were previously correlated with higher lake trophy (Barnett \& Beisner, 2007; Sodré \& Bozelli, 2019). Therefore, high water trophy in PRZ led to the prevalence of species characterized by small size and different trophic type, and it also supported colonization by many eutrophic species, confirmed by RDA analysis. The above contributed to high taxonomic diversity but low lake functionality, indicated by low gradient related to the ratio of zooplankton trophic groups (GR'). A dominance of LMF was observed throughout the entire study, and it is indicative of ecosystem disturbance and functional depletion (homogenization) of PRZ (Hampton, 2005; Hogsten et al., 2009). According to Petchey (2009), prolonged and unidirectional use of food resources can compromise an ecosystem's resistance and contribute to its degradation.
PRZ is subjected to high levels of anthropogenic pressure (water recreation, fishing, possible sewage inflows) and is characterized by small volume; therefore, eutrophication proceeded rapidly. The analyzed lake's productivity increased 11-fold during the twoyear study (2016 and 2017), which prompted a rapid response from both zooplankton taxa (Bray-Curtis dissimilarity index) and feeding guilds. Obertegger and Manca (2011) demonstrated that fluctuations in water trophy significantly influence competition among rotifers. Microphagous rotifers dominate in lakes characterized by higher trophy, whereas raptorials are most prevalent when trophic characteristic are low. These variations can be attributed to the availability of food sources. According to Galir Balkic et al. (2018), small filtering zooplankton such as the smallest rotifers generally play a minor and relatively stable role in algal grazing, even during rapid fluctuations in environmental conditions, probably due to a high share of detritus in their diet. However, during dense phytoplankton blooms (Chl- $\left.a=59.9 \mu \mathrm{g} \mathrm{l}^{-1}\right)$ in PRZ in 2017, the grazing efficiency of SMF increased by $50 \%$ on average, whereas their abundance remained similar relative to 2016 . The above observation was attributed to the fact that the small Keratella cochlearis had been replaced by Copepoda nauplii which grazed more efficiently on algal blooms. According to Kim et al. (2000), copepod nauplii are more effective filter feeders than many Rotifera species, including $K$. cochlearis; and this difference is particularly pronounced when both groups graze on algae. In the analyzed case, this taxonomic replacement occurred during dense phytoplankton blooms (Chl- $a>20 \mu \mathrm{g} \mathrm{l}^{-1}$; Kawecka \& Eloranta, 1994) with a dominance ( $>50 \%$ quantitative proportion) of Microcystis aeruginosa (Kützing) Kützing 1846, Aphanizomenon sp. and Pseudanabaena mucicola (Naumann \& Hub.-Pest.) Schwabe 1964 cyanobacteria (Table 1). Zhao et al. (2008) observed that high copepod functionality is associated with selective feeding on alternative food sources, such as diatoms, detritus and green algae, during cyanobacterial blooms, whereas Rotifera and Cladocera (non-selective filter-feeders with identical feeding preferences) can be limited or eliminated.

Cyanobacteria forming large mucilaginous colonies or large filaments with aerotopes (such as the above species) are generally not a suitable food source for rotifers (Colina et al., 2015), but large populations 
of LMF (Keratella quadrata, Brachionus angularis) and RAP (Polyarthra spp., Trichocerca similis) were identified in PRZ. According to Soares et al. (2010) and Galir Balkić et al. (2018), this could be the result of adaptation to cyanobacteria in their diet ( $\mathrm{Bra}$ chionus), grazing on alternative food sources such as bacteria and detritus ( $K$. quadrata), or switching to animal food resource, such as protozoa (T. similis). Tõnno et al. (2016) showed resistance and/or feeding selectivity of small Cladocera species, including $C h$. sphaericus towards cyanobacterial colonies, which explains/allows their presence during bloom. These effects were observed in PRZ in 2017 when algivorous species dominated other trophic groups in terms of grazing efficiency, which points to strong interactions with the food web.

The oligotrophic conditions in JAN occupied the opposite end of the gradient relative to the eutrophic PRZ, which could be attributed to the absence of anthropogenic influences in JAN which is not open for public use. This comparison revealed that the content of ions in the water $\left(\mathrm{TH}, \mathrm{Ca}^{2+}, \mathrm{EC}, \mathrm{Cl}^{-}\right)$, resulting from the geochemical properties of excavated pits, exert a significant direct and indirect influence on ecosystem, including the trophic state of lakes.

The concentration of calcium cations plays a major role in food webs by promoting optimal water hardness $\left(1.5-4 \mathrm{mval}^{-1}\right.$ and $>2 \mathrm{mg} \mathrm{Ca}^{2+} 1^{-1}$ ) (Wurts \& Durborow, 1992; Hessen et al., 2000; Korosi et al., 2012; Boyd et al., 2016). Water hardness in JAN and the remaining lakes was within the upper range of the cited values, whereas the concentration of calcium cations exceeded the critical minimum threshold 20- to 40-fold. Therefore, these factors could not directly disrupt life processes (osmoregulation, growth, reproduction) of planktonic crustaceans, and similar observations were made by Hessen et al. (1995), Wærvågen et al. (2002), Ashforth \& Yan (2008), and Jeziorski et al. (2012). However, calcium concentration in the oligomesotrophic JAN was nearly two-fold higher, and chlorophyll $a$ concentration was approximately six-fold lower than in the eutrophic PRZ lake. The above indicates that $\mathrm{Ca}^{2+}$ could be the main regulator of phytoplankton productivity and species composition which influenced the availability of phosphorus, the principal nutrient (Korosi et al., 2012; Boyd et al., 2016). In JAN, the phosphorus balance could also have been affected by stoneworts (Characeae) which densely colonized the lake bottom in both shallow and deep zones. According to Kufel \& Ozimek (1994), these macroalgae are characteristic of hard mesotrophic waters with low phosphorus content. Phosphorus is also more rapidly accumulated by Chara spp. than by other aquatic plants (macrophytes and phytoplankton), thus eliminating or inhibiting the development of these trophic groups through competition for food or allelopathy (Kufel \& Kufel, 2002; Lürling et al., 2006). Low phosphorus levels in JAN contributed to the abundance of planktonic algae of the genus Dinobryon (Chrysophyceae). The diet of representatives of this mixotrophic genus may also include bacteria, therefore they often dominate in oligotrophic water bodies, forming large and numerous colonies (Sommer et al., 2003; Kamjunke et al., 2007; Padisák et al., 2009). Regardless of its phenology, the genus Dinobryon (which occurs in cool seasons of the year, including spring; Heinze et al., 2013) was observed during the entire study in JAN, and its abundance peaked in August 2017. The above also indicates that low phosphorus concentration was a permanent, rather than a seasonal characteristic of JAN.

Lower water trophy in JAN than in PRZ led to a four-fold decrease in total zooplankton abundance. Ecosystems with low trophic characteristic (oligotrophic lakes, flowing waters) are generally characterized by abundance of Rotifera species which have a short life cycle and low nutritional requirements in comparison with crustaceans (Baranyi et al., 2002; Goździejewska et al., 2010; Goździejewska et al., 2016). However, rotifers were least abundant in JAN. The above could have directly resulted from the absence of flagellates such as Dinobryon in rotifer diets. In turn, a high concentration of dissolved calcium in JAN and the availability of large Dinobryon colonies probably contributed to the development and survival of large planktonic crustaceans which were abundantly represented by Ceriodaphnia quadrangula and Eudiaptomus graciloides. These species are highly effective filtering feeders and grazers, and they effectively competed for food resources with SMF, and, possibly, directly eliminated SMF from the environment by mechanical interference them in filtering chambers (Sommer et al., 2003; Balvert et al., 2009).

The abundance of many Rotifera species in JAN could also be limited by high electrolytic conductivity (EC). The EC of natural fresh water bodies is usually positively correlated with their trophic status 
(concentrations of nutrients and chlorophyll $a$ ) (Bērzinš̌ \& Pejler, 1989; Diaz et al., 2007; Brito et al., 2011). In man-made reservoirs, including mine pit lakes, EC is often correlated with the presence of dissociated carbonate, chloride and sulfate ions or heavy metals (Molenda, 2014; Pociecha \& BielańskaGrajner, 2015). The RDA indicated strong correlations between EC and all parameters responsible for EC $\left(\mathrm{Ca}^{2+}, \mathrm{TH}, \mathrm{Cl}^{-}\right)$. Electrolytic conductivity was bound by a negative correlation with TP and Chl- $a$, which indicates that EC strongly influenced the functioning of plankton communities in JAN. The quantitative composition of species in JAN was dominated by $K$. cochlearis (SMF) and Polyarthra spp. (RAP)-rotifers that are capable of colonizing multiple environments, including mine pit lakes with high EC (EC $>600 \mu \mathrm{s}^{-1}$; Bielańska-Grajner \& Gładysz, 2010; Pociecha \& Bielańska-Grajner, 2015). Therefore, ion concentrations in JAN appear to play an important role, by favouring specific functional traits of zooplankton, such as large body size in Cladocera (Ceriodaphnia) and Copepoda (Eudiaptomus). Ion concentrations is also responsible for competition in the food web (elimination of rotifers) and the homogenization of phytoplankton resources in a reservoir with permanently low TP levels. As a result, the trophic structure of zooplankton was based on the codominance of LMF and STA/SUS throughout the entire study. The above was responsible for the low trophic gradient of zooplankton feeding guild taxa, and it testifies to the low functionality of the JAN ecosystem (Moreira et al., 2016).

The observed changes in environmental conditions, which were reflected by planktonic structures in WLA, resulted from early dynamic ecological succession processes as well as depth gradient. According to Gammons et al. (2009) and Audet et al. (2013), the abundance and diversity of zooplankton and phytoplankton are a function of the time elapsed since a lake's formation. WLA was characterized by a predominance of Pyrrophyta (genera Peridinium and Ceratium), which are often regarded as pioneer species in mine pit lakes younger than 10 years (Gammons et al., 2009). These freshwater dinoflagellates have a vertical distribution pattern, and they accumulate at depths that are optimal for photosynthesis (Regel et al., 2004; Darki \& Krakhmalnyi, 2019). As a result, oxygen levels increase in the metalimnion (at a depth of approx. 8-9 $\mathrm{m}$ in this study) as an effect of intensive photosynthesis and favorable light conditions.

The variations in phytoplankton structure and biomass in stratified lakes induced by a vertical gradient of light, temperature and density (EC) significantly differentiate habitats and the structure of zooplankton communities (Obertegger \& Flaim, 2018). Oxygen saturation is yet another important factor that changes with depth (Karpowicz et al., 2020). In WLA, most of the dominant zooplankton species colonized the epi-metalimnion. In 2016, Diaphanosoma brachyurum (Liévin, 1848), a large filter feeder, was the dominant species mostly in the polymictic layer (epilimnion); whereas in 2017, the availability of Peridinium and Ceratium as food resources led to colonization by efficient raptorial consumers Ascomorpha ovalis, Polyarthra spp. and Gastropus stylifer, mostly in metalimnetic conditions (Stelzer, 1998). The above changes in zooplankton community can be also attributed to top-down biotic factors associated with fish pressure on planktonic crustaceans. In the future, there are plans to stock WLA with fish for recreational purposes (Stachowski et al., 2018). However, the reservoir has been already colonized by fish as a result of natural processes and uncontrolled stocking (Skrzypczak et al., 2019). Thermophilic fish most readily graze in the epimetalimnion where they prey on large and slow organisms (Cladocera). Therefore, migrating crustaceans often find shelter in deeper parts of the pelagic zone (hypolimnion) during the day (Gauthier et al., 2014, Karpowicz et al., 2020). However, these layers may be less accessible due to decreased availability of nutrients (lower primary production) and progressing oxygen depletion. Oxygen stress can affect both taxonomic and functional structure of zooplankton as small species replace large ones. These processes are intensified with hypoxic conditions (DO $<2 \mathrm{mg} \mathrm{l}^{-1}$ ) (Karpowicz et al., 2020). In the hypolimnion of WLA, oxygen concentrations at a depth of $25 \mathrm{~m}$ and temperature of around $6.5^{\circ} \mathrm{C}$ ranged from 5.4 to $7.7 \mathrm{mg} \mathrm{l}^{-1}$. These conditions did not compromise the activity of grazing raptorials represented by numerous populations of large-sized copepods Cyclops vicinus and C. scutifer G.O. Sars, 1863.

This study confirmed that the depth gradient significantly contributed to variations in habitats and food niches in the young ecosystem of WLA. However, these observations were not confirmed by the 
values of biodiversity indices, and the species diversity of zooplankton was lowest in WLA relative to JAN and PRZ. In turn, the highest value of GR' in WLA could be attributed to differences in trophic characteristic in two successive years of the study and between depth zones. The predominance of raptorials in WLA is indicative to low water trophy levels and the scarcity of phytoplankton, which means low density and/or dominance of large algae species, unavailable to filter feeders (Obertegger \& Manca, 2011).

\section{Conclusions}

The taxonomic diversity and functionality of zooplankton in the mine pit lakes were determined by the selective influence of environmental conditions. High primary production contributed to taxonomic heterogeneity, but it led to the functional homogeneity of plankton communities with a dominance of cyanobacteria and functionally specialized rotifers and crustaceans (microphagous rotifers and small-sized crustaceans). Low primary production, oligotrophy and high ion concentrations contributed to high species diversity of zooplankton and the functional simplification of the plankton community with a predominance of Dinobryon colonies and large-sized Cladocera (LMF) and Calanoida (STA/SUS). In this case, geochemical properties were a strong and stable influencing factor which led to the development of permanent competitive and allelopathic (Characeae) relationships in plankton communities and consequently their homogenization. The ecosystem of the deep stratified lake was characterized by greater spatial heterogeneity of habitats and food niches due to a vertical gradient of temperature, light, oxygen saturation and water density. Large thermophilic filter feeders and raptorial rotifers grazed in the epimetalimnion. Large-sized Copepoda that are resistant to oxygen stress found refuge against predatory fish in the hypolimnion.

Post mine lakes are a unique phenomenon of the formation of "new" ecosystems. It is possible to observe ecosystem changes related to the early stages of biological succession in these lakes. Our analyses of zooplankton functional traits showed the stable effects of oligotrophy and the dynamics of formation of the new ecosystem. They are also an excellent tool for monitoring threats in aquatic ecosystems resulting from anthropogenic pressure.

Acknowledgements The project was financially supported by the Minister of Science and Higher Education under the program entitled "Regional Initiative of Excellence" for 2019-2022 (project No. 010/RID/2018/19, amount of funding: PLN $12,000,000)$. This research was substantially funded by the University of Warmia and Mazury in Olsztyn (18.610.010-110) and conducted with the kind cooperation of the Lignite Division of the Adamów Coal Mine. The authors would like to thank Andrzej Skrzypczak and Radosław Niestrata for assistance in field research, and Magdalena Grabowska for invaluable insights on phytoplankton.

Open Access This article is licensed under a Creative Commons Attribution 4.0 International License, which permits use, sharing, adaptation, distribution and reproduction in any medium or format, as long as you give appropriate credit to the original author(s) and the source, provide a link to the Creative Commons licence, and indicate if changes were made. The images or other third party material in this article are included in the article's Creative Commons licence, unless indicated otherwise in a credit line to the material. If material is not included in the article's Creative Commons licence and your intended use is not permitted by statutory regulation or exceeds the permitted use, you will need to obtain permission directly from the copyright holder. To view a copy of this licence, visit http://creativecommons.org/licenses/by/4.0/.

\section{References}

APHA-AWWA-WEF, 1999. In Clesceri, L. S. \& A. E. Greenberg, \& A. D. Eaton (eds), Standard methods for the examination of water and wastewater (20th ed.). American Public Health Association, American Water Works Association, Water Environment Federation. Washington DC. Retrieved from www.mwa.co.th/download/file_upload/ SMWW_1000-3000.pdf

Ashforth, D. \& N. D. Yan, 2008. The interactive effects of calcium concentration and temperature on the survival and reproduction of Daphnia pulex at high and low food concentrations. Limnology and Oceanography 53: 420-432.

Audet, Ch, S. Mac Phee \& W. Keller, 2013. Constructed ponds colonised by crustacean zooplankton: local and regional influences. Journal of Limnology 72: 524-530.

Axler, R., S. Yokom, C. Tikkanen, M. McDonald, H. Runke, D. Wilcox \& B. Cady, 1998. Restoration of a mine pit lake from aquacultural nutrient enrichment. Restoration Ecology 6: 1-19.

Balvert, S. F., I. C. Duggan \& I. D. Hogg, 2009. Zooplankton seasonal dynamics in a recently filled mine pit lake: The effect of non-indigenous Daphnia establishment. Aquatic Ecology 43: 403-413.

Baranyi, C., T. Hein, C. Holarek, S. Keckeis \& F. Schiemer, 2002. Zooplankton biomass and community structure in a 
Danube River floodplain system: effects of hydrology. Freshwater Biology 47: 473-482.

Barnett, A. \& B. E. Beisner, 2007. Zooplankton biodiversity and lake trophic state: explanations invoking resource abundance and distribution. Ecology 88(7): 1675-1686.

Bertani, I., I. Ferrari \& G. Rossetti, 2012. Role of intra-community biotic interactions in structuring riverine zooplankton under low-flow, summer conditions. Journal of Plankton Research 34: 308-320.

Bērzinš̌, B. \& B. Pejler, 1989. Rotifer occurrence and trophic degree. Hydrobiologia 182: 171-180.

Bielańska-Grajner, I. \& A. Gładysz, 2010. Planktonic rotifers in mining lakes in the Silesian Upland: relationship to environmental parameters. Limnologica 40: 67-72.

Blanchette, M. L. \& M. A. Lund, 2016. Pit lakes are a global legacy of mining: an integrated approach to achieving sustainable ecosystems and value for communities. Science Direct 23: 28-34.

Błędzki, L. A. \& J. I. Rybak, 2016. Freshwater crustacean zooplankton of Europe: Cladocera \& Copepoda (Calanoida, Cyclopoida). Key to species identification with notes on ecology, distribution, methods and introduction to data analysis. Springer International Publishing, Basel.

Boersma, K. S., L. E. Dee, S. J. Miller, M. T. Bogan, D. A. Lytle \& A. I. Gitelman, 2016. Linking multidimensional functional diversity to quantitative methods: a graphical hypothesis-evaluation framework. Ecology 97: 583-593.

Booth, B. D. \& C. J. Swanton, 2002. 50th Anniversary-Invited Article. Assembly theory applied to weed communities. Weed Science 50: 2-13.

Bottrell, H. H., A. Duncan, Z. M. Gliwicz, E. Grygierek, A. Herzig, A. Hillbicht-Ilkowska, H. Kurasawa, P. Larsson \& T. Wegleńska, 1976. A review of some problems in zooplankton production studies. Norwegian Journal of Zoology 24: 419-456.

Boyd, C. E., C. S. Tucker \& B. Somridhivej, 2016. Alkalinity and hardness: critical but elusive concepts in aquaculture. Journal of the World Aquaculture Society 47: 6-41.

Brito, S. L., P. M. Maia-Barbosa \& R. M. Pinto-Coelho, 2011. Zooplankton as an indicator of trophic conditions in two large reservoirs in Brazil. Lakes \& Reservoirs: Research and Management 16: 253-264.

Carlson, R. E., 1977. A trophic state index for lakes. Limnology and Oceanography 22(2): 362-369.

Chesson, P., 2000. Mechanisms of maintenance of species diversity. Annual Review of Ecology, Evolution, and Systematics. 31: 343-366.

Colina, M., D. Calliari, C. Carballo \& C. Kruk, 2015. A traitbased approach to summarize zooplankton-phytoplankton interactions in freshwaters. Hydrobiologia 767: 221-233.

Cornwell, W. K., D. W. Schwilk \& D. D. Ackerly, 2006. A traitbased test for the habitat filtering: convex hull volume. Ecology 87: 1465-1471.

Darki, B. Z. \& A. F. Krakhmalnyi, 2019. Biotic and abiotic factors affecting the population dynamics of Ceratium hirundinella, Peridinium cinctum, and Peridiniopsis elpatiewskyi. Diversity 11: 137. https://doi.org/10.3390/ d11080137.

Diaz, M., F. Pedrozo, C. Reynolds \& P. Temporetti, 2007. Chemical composition and the nitrogen-regulated trophic state of Patagonian lakes. Limnologica 37: 17-27.
Ejsmont-Karabin, J., 1998. Empirical equations for biomass calculation of planktonic rotifers. Polskie Archiwum Hydrobiologii 45: 513-522.

Ejsmont-Karabin, J., 2012. The usefulness of zooplankton as lake ecosystem indicators: rotifer trophic state index. Polish Journal of Ecology 60: 339-350.

Ejsmont-Karabin, J. \& A. Karabin, 2013. The suitability of zooplankton as lake ecosystem indicators: crustacean trophic state index. Polish Journal of Ecology 61: 561-573.

Ejsmont-Karabin, J., S. Radwan \& I. Bielańska-Grajner, 2004. Fauna słodkowodna Polski. Wrotki. Zeszyt 32A and 32B. Oficyna Wydawnicza Tercja, Łódź: 1-447.

El-Bassat, R. A. \& W. D. Taylor, 2007. The zooplankton community of Lake Abo Zaabal, a newly-formed mining lake in Cairo. Egypt. African Journal of Aquatic Science 32: 185-192.

Galir Balkić, A., I. Ternjej \& M. Špoljar, 2018. Hydrology driven changes in the rotifer trophic structure and implications for food web interactions. Ecohydrology 11: https://doi.org/10.1002/eco.1917.

Gammons, C. H., L. N. Harris, J. M. Castro, P. A. Cott \& B. W. Hanna, 2009. Creating lakes from open pit mines: processes and considerations - with emphasis on northern environments. Canadian Technical Report of Fisheries and Aquatic Sciences 2826: ix + 106 p. Available at http:// digitalcommons.mtech.edu/geol_engr/2

Gauthier, J., Y. T. Prairie \& B. E. Beisner, 2014. Thermocline deepening and mixing alter zooplankton phenology, biomass and body size in a whole-lake experiment. Freshwater Biology 59: 998-1011.

Goździejewska, A., A. Skrzypczak, A. Florczyk \& L. Szwed, 2019b. Post-mining and technological reservoirs in brown coal mines - ecological features and similarities to natural ecosystems. In Cała, M. J. Schlenstedt \& A. Ostręga (eds), The Reclamation and Revitalisation of Post-Mining Areas in Poland and Germany. Planning, Natural and Cultural Considerations. AGH, Kraków. ISBN 978-83-66016-67-5. Available at www.rewitalizacja.agh.edu.pl/forum/

Goździejewska, A., A. Skrzypczak, G. Furgała-Selezniow, J. Koszałka \& A. Mamcarz, 2010. Zooplankton in the Nida River (The Upper Wkra River) Subjected to revitalization treatments. Polish Journal of Natural Science 25: 387-400.

Goździejewska, A., K. Glińska-Lewczuk, K. Obolewski, M. Grzybowski, R. Kujawa, S. Lew \& M. Grabowska, 2016. Effects of lateral connectivity on zooplankton community structure in floodplain lakes. Hydrobiologia 774: 7-21.

Goździejewska, A. M., M. Gwoździk, S. Kulesza, M. Bramowicz \& J. Koszałka, 2019a. Effects of suspended micro- and nanoscale particles on zooplankton functional diversity of drainage system reservoirs at an open-pit mine. Scientific Reports 9: 16113. https://doi.org/10.1038/ s41598-019-52542-6.

Gutierrez, M. F., Ü. N. Tavşanoğlu, N. Vidal, J. Yu, F. Teixeirade Mello, A. I. Çakiroglu, H. He, Z. Liu \& E. Jeppesen, 2018. Salinity shapes zooplankton communities and functional diversity and has complex effects on size structure in lakes. Hydrobiologia 813: 237-255.

Hampton, S. E., 2005. Increased niche differentiation between two Conochilus species over 33 years of climate change and food web alteration. Limnology and Oceanography 50: 421-426. 
Heinze, A. W., C. L. Truesdale, S. B. DeVaul, J. Swinden \& R. W. Sanders, 2013. Role of temperature in growth, feeding, and vertical distribution of the mixotrophic chrysophyte Dinobryon. Aquatic Microbial Ecology 71: 155-163.

Hessen, D. O., B. A. Faafeng \& T. Andersen, 1995. Replacement of herbivore zooplankton species along gradients of ecosystem productivity and fish predation pressure. Canadian Journal of Fisheries and Aquatic Sciences 52: 433-742.

Hessen, D. O., N. E. W. Alstad \& L. Skarda, 2000. Calcium limitation in Daphnia magna. Journal of Plankton Research 22: 553-568.

Hogsten, K. L., M. A. Xenopoulos \& J. A. Rusak, 2009. Asymmetrical food web responses in trophic-level richness, biomass, and function following lake acidification. Aquatic Ecology 43: 591-606.

Jeziorski, A., A. M. Paterson \& J. P. Smol, 2012. Crustacean zooplankton sedimentary remains from calcium-poor lakes: complex responses to threshold concentrations. Aquatic Sciences 74: 121-131.

Jongman, R. H. G., C. J. F. ter Braak \& O. F. R. van Tongeren, 1995. Data analysis in community and landscape ecology 324. Cambridge University Press, Cambridge.

Kalin, M., Y. Cao, M. Smith \& M. M. Olaveson, 2001. Development of the phytoplankton community in a pit-lake in relation to water quality changes. Water Research 35: 3215-3225.

Kamjunke, N., T. Henrichs \& U. Gaedke, 2007. Phosphorus gain by bacterivory promotes the mixotrophic flagellate Dinobryon spp. during re-oligotrophication. Journal of Plankton Research 29(1): 39-46.

Karpowicz, M., J. Ejsmont-Karabin, J. Kozłowska, I. Feniova \& A. R. Dzialowski, 2020. Zooplankton community responses to oxygen stress. Water 12: 706. https://doi.org/10. 3390/w12030706.

Kasprzak, K. \& W. Niedbała, 1981. Biocenotic indices in quantitative study. In Górny, M. \& L. Grüm (eds.), Methods Applied in Soil Zoology 396-416. PWN, Warsaw.

Kawecka, B. \& P. V. Eloranta, 1994. Zarys ekologii glonów wód słodkich i środowisk lądowych. [Outline of ecology of freshwater and terrestrial algae]. PWN, Warszawa: 252.

Kim, H.-W., S.-J. Hwang \& G.-J. Joo, 2000. Zooplankton grazing on bacteria and phytoplankton in a regulated large river (Nakdong River, Korea). Journal of Plankton Research 22: 1559-1577.

Kleeberg, A., A. Schapp \& D. Biemelt, 2008. Phosphorus and iron erosion from non-vegetated sites in a post-mining landscape, Lusatia, Germany: impact on aborning mining lakes. Catena 72: 315-324.

Korosi, J. B., S. M. Burke, J. R. Thienpont \& J. P. Smol, 2012. Anomalous rise in algal production linked to lakewater calcium decline through food web interactions. Proceedings of the Royal Society B 279: 1210-1217.

Koste, W., 1978. Rotatoria. Die Rädertiere Mitteleuropas. Überordnung Monogononta. I Textband, II Tafelband 52-570. Gebrüder Borntraeger, Berlin.

Kovach, W. L., 2015. MVSP - a Multivariate statistical package for windows, ver. 3.2. Kovach Computing Services Pentraeth, Wales.

Kufel, L. \& I. Kufel, 2002. Chara beds acting as nutrient sinks in shallow lakes-a review. Aquatic Botany 72: 249-260.
Kufel, L. \& T. Ozimek, 1994. Can Chara control phosphorus cycling in Lake Luknajno (Poland)? Hydrobiologia 275(276): 277-283.

Kumar, R. N., C. D. McCullough \& M. A. Lund, 2009. Water resources in australian mine pit lakes. Mining Technology 118: 205-211.

Lampert, W., 1988. The relationship between zooplankton biomass and grazing: a review. Limnologica 19: 11-20.

Larondelle, N. \& D. Haase, 2012. Valuing post-mining landscapes using an ecosystem services approach—an example from Germany. Ecological Indicators 18: 567-574.

Lechner, A. M., N. McIntyre, K. Witt, C. M. Raymond, S. Arnold, M. Scott \& W. Rifkin, 2017. Challenges of integrated modelling in mining regions to address social, environmental and economic impacts. Environmental Modelling \& Software 93: 268-281.

Lei, K., H. Pan \& C. Lin, 2016. A landscape approach towards ecological restoration and sustainable development of mining areas. Ecological Engineering 90: 320-325.

Lokko, K., T. Virro \& J. Kotta, 2017. Seasonal variability in the structure and functional diversity of psammonic rotifer communities: role of environmental parameters. Hydrobiologia 796: 287-307.

Lürling, M., G. van Geest \& M. Scheffer, 2006. Importance of nutrient competition and allelopathic effects in suppression of the green alga Scenedesmus obliquus by the macrophytes Chara, Elodea and Myriophyllum. Hydrobiologia 556: 209-220.

Marszelewski, W., E. Dembowska, P. Napiórkowski \& A. Solarczyk, 2017. Understanding abiotic and biotic conditions in post-mining pit lakes for efficient management: a case study (Poland). Mine Water and the Environment 36: 418-428.

McCullough, C. D. \& M. A. Lund, 2006. Opportunities for sustainable mining pit lakes in Australia. Mine Water and the Environment 25: 220-226.

Molenda, T., 2014. Physical-chemical properties of coal mine waters of old adits and spring waters. Polish Journal of Environmental Studies 23: 393-399.

Moody, E. K. \& G. M. Wilkinson, 2019. Functional shifts in lake zooplankton communities with hypereutrophication. Freshwater Biology 64: 608-616.

Moreira, F. W. A., M. G. P. Leite, M. A. G. Fujaco, F. P. C. Mendonça, L. P. Campos \& E. M. Eskinazi-Sant'Anna, 2016. Assessing the impacts of mining activities on zooplankton functional diversity. Acta Limnologica Brasiliensia 28: https://doi.org/10.1590/S2179-975X0816.

Naeem, S. \& J. P. Wright, 2003. Disentangling biodiversity effects on ecosystem functioning: deriving solutions to a seemingly insurmountable problem. Ecology Letters 6: $567-579$.

Nixdorf, B., D. Lessmann \& R. Deneke, 2005. Mining lakes in disturbed landscape: apliccation of the EC Water Framework Directive and future management strategies. Ecological Engineering 24: 67-73.

Obertegger, U. \& G. Flaim, 2018. Taxonomic and functional diversity of rotifers, what do they tell us about community assembly? Hydrobiologia 823(79-91):

Obertegger, U. \& M. Manca, 2011. Response of rotifer functional groups to changing trophic state and crustacean community. Journal of Limnology 70(2): 231-238. 
Obertegger, U., H. A. Smith, G. Flaim \& R. L. Wallace, 2011. Using the guild ratio to characterize pelagic rotifer communities. Hydrobiologia 662: 157-162.

Oh, H.-J., H.-G. Jeong, G.-S. Nam, Y. Oda, W. Dai, E.-H. Lee, D. Kong, S.-J. Hwang \& K.-H. Chang, 2017. Comparison of taxon-based and trophi-based response patterns of rotifer community to water quality: applicability of the rotifer functional group as an indicator of water quality. Animal Cells and Systems 21: 133-140.

Padisák, J., L. O. Crossetti \& L. Naselli-Flores, 2009. Use and misuse in the application of the phytoplankton functional classification: a critical review with updates. Hydrobiologia 621: 1-19.

Parravicini, V., S. Villéger, T. R. McClanahan, J. E. AriasGonzález, D. R. Bellwood, J. Belmaker, P. Chabanet, S. R. Floeter, A. M. Friedlander, F. Guilhaumon, L. Vigliola, M. Kulbicki \& D. Mouillot, 2014. Global mismatch between species richness and vulnerability of reef fish assemblages. Ecology Letters 17: 1101-1110.

Petchey, O. L., E. O. O'Gorman \& D. F. B. A. Flynn, 2009. Functional guide to functional diversity measures. In Naeem, S., D. E. Bunker, A. Hector, M. Loreau \& C. Perrings (eds.), Biodiversity, ecosystem functioning, and human wellbeeing. Oxford University Press, Oxford: 49-59.

Pociecha, A. \& I. Bielańska-Grajner, 2015. Large-scale assessment of planktonic organisms biodiversity in artificial water reservoirs in Poland. IOP PAN, Kraków: 269.

Pomerleau, C., A. R. Sastri \& B. E. Beisner, 2015. Evaluation of functional trait diversity for marine zooplankton communities in the Northeast subarctic Pacific Ocean. Journal of Plankton Research 37(4): 712-726.

Regel, R. H., J. D. Brookes \& G. G. Ganf, 2004. Vertical migration, entrainment and photosynthesis of the freshwater dinoflagellate Peridinium cinctum in a shallow urban lake. Journal of Plankton Research 26: 143-157.

Różkowski, K., K. Polak \& M. Cała, 2010. Wybrane problemy związane z rekultywacją wyrobisk w kierunku wodnym. Górnictwo i Geoinżynieria 34: 517-525.

Rybak, J. I. \& L. A. Błędzki, 2010. Freshwater planktonic crustaceans. Warsaw University Press, Warsaw.

Simões, N. R., L. S. M. Braghin, G. A. V. Duré, J. S. Santos, S1 L. Sonoda \& C. C. Bonecker, 2020. Changing taxonomic and functional $\beta$-diversity of cladoceran communities in Northeastern and South Brazil. Hydrobiologia. https://doi. org/10.1007/s10750-020-04234-w.

Skrzypczak, A., A. Goździejewska, E. Karpiński, A. Florczyk \& L. Szwed, 2019. Recreational fishing and fisheries as a utilitarian function of brown coal mine tailing ponds and post-mining reservoirs. In Cała, M. J. Schlenstedt \& A. Ostręga (eds), The Reclamation and Revitalisation of PostMining Areas in Poland and Germany. Planning, Natural and Cultural Considerations. AGH, Kraków. ISBN 978-8366016-67-5. Available at www.rewitalizacja.agh.edu.pl/ forum/

Sloss, L., 2013. Coal mine site reclamation. IEA Clean Coal Centre, CCC/216 ISBN 978-92-9029-536-5.

Smith, H. A., J. Ejsmont-Karabin, T. M. Hess \& R. L. Wallace, 2009. Paradox of planktonic rotifers: similar structure but unique trajectories in communities of the Great Masurian Lakes (Poland). Verhandlungen des Internationalen Verein Limnologie 30: 951-956.

Soares, M. C. S., M. Lürling \& V. L. M. Huszar, 2010. Responses of the rotifer Brachionus calyciflorus to two tropical toxic cyanobacteria (Cylindrospermopsis raciborskii and Microcystis aeruginosa) in pure and mixed diets with green algae. Journal of Plankton Research 32: 999-1008.

Sodré, E. D. O. \& R. L. Bozelli, 2019. How planktonic microcrustaceans respond to environment and affect ecosystem: a functional trait perspective. International Aquatic Research 11: 207-223.

Sommer, U., F. Sommer, B. Santer, E. Zöllner, K. Jürgens, C. Jamieson, M. Boersma \& K. Gocke, 2003. Daphnia versus copepod impact on summer phytoplankton: functional compensation at both trophic levels. Oecologia 135: 639-647.

Stachowski, P., D. Liberacki \& K. Kraczkowska, 2018. Zagospodarowanie zbiornika wodnego wraz z otoczeniem na terenie zdewastowanym. Acta Scientiarum Polonorum, Administratio Locorum 17: 75-85.

Stelzer, C.-P., 1998. Feeding behaviour of the rotifer Ascomorpha ovalis: functional response, handling time and exploitation of individual Ceratium cells. Journal of Plankton Research 20: 1131-1144.

ter Braak, C. J. F. \& P. Šmilauer, 2002. CANOCO reference manual and canodraw for windows user's guide: software for canonical community ordination (version 4.5). Microcomputer Power, Ithaca, NY, USA. www.canoco.com.

Tõnno, I., H. Agasild, T. Kõiv, R. Freiberg, P. Nõges \& T. Nõges, 2016. Algal diet of small-bodied crustacean zooplankton in a Cyanobacteria-dominated eutrophic lake. PLoS ONE 11: https://doi.org/10.1371/journal.pone. 0154526.

Vogt, R. J., P. R. Peres-Neto \& B. E. Beisner, 2013. Using functional traits to investigate the determinants of crustacean zooplankton community structure. Oikos 122: 1700-1709.

von Flössner, D., 1972. Krebstiere, Crustacea. Kiemen-und Blattfüsser, Branchiopoda, Fischläuse, Branchiura 382. VEB Gustav Fischer Verlag, Jena.

Wærvågen, S. B., N. A. Rukke \& D. O. Hessen, 2002. Calcium content of crustacean zooplankton and its potential role in species distribution. Freshwater Biology 47: 1866-1878.

Wurts, W. A. \& R. M. Durborow, 1992. Interactions of $\mathrm{pH}$, carbon dioxide, alkalinity and hardness in fish ponds. Southern Regional Aquaculture Center Publication 464. Available at https://agrilifecdn.tamu.edu/fisheries/files/ 2013/09/SRAC

Zhao, J., M. Ramin, V. Cheng \& G. B. Arhonditsis, 2008. Plankton community patterns across a trophic gradient: the role of zooplankton functional groups. Ecological Modelling 213: 417-436.

Publisher's Note Springer Nature remains neutral with regard to jurisdictional claims in published maps and institutional affiliations. 